\title{
Sulfur dioxide emissions in China and sulfur trends in East Asia since 2000
}

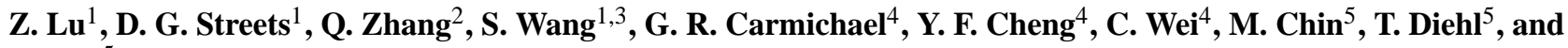 \\ Q. $\operatorname{Tan}^{5}$ \\ ${ }^{1}$ Decision and Information Sciences Division, Argonne National Laboratory, Argonne, IL 60439, USA \\ ${ }^{2}$ Center for Earth System Science, Tsinghua University, Beijing 100084, China \\ ${ }^{3}$ Department of Environmental Science and Engineering, Tsinghua University, Beijing 100084, China \\ ${ }^{4}$ Center for Global and Regional Environmental Research, University of Iowa, Iowa City, IA 52242, USA \\ ${ }^{5}$ Laboratory for Atmospheres, NASA Goddard Space Flight Center, Greenbelt, MD 20771, USA
}

Received: 27 February 2010 - Published in Atmos. Chem. Phys. Discuss.: 6 April 2010

Revised: 15 June 2010 - Accepted: 3 July 2010 - Published: 13 July 2010

\begin{abstract}
With the rapid development of the economy, the sulfur dioxide $\left(\mathrm{SO}_{2}\right)$ emission from China since 2000 is of increasing concern. In this study, we estimate the annual $\mathrm{SO}_{2}$ emission in China after 2000 using a technology-based methodology specifically for China. From 2000 to 2006, total $\mathrm{SO}_{2}$ emission in China increased by $53 \%$, from $21.7 \mathrm{Tg}$ to $33.2 \mathrm{Tg}$, at an annual growth rate of $7.3 \%$. Emissions from power plants are the main sources of $\mathrm{SO}_{2}$ in China and they increased from $10.6 \mathrm{Tg}$ to $18.6 \mathrm{Tg}$ in the same period. Geographically, emission from north China increased by $85 \%$, whereas that from the south increased by only $28 \%$. The emission growth rate slowed around 2005, and emissions began to decrease after 2006 mainly due to the wide application of flue-gas desulfurization (FGD) devices in power plants in response to a new policy of China's government. This paper shows that the trend of estimated $\mathrm{SO}_{2}$ emission in China is consistent with the trends of $\mathrm{SO}_{2}$ concentration and acid rain $\mathrm{pH}$ and frequency in China, as well as with the increasing trends of background $\mathrm{SO}_{2}$ and sulfate concentration in East Asia. A longitudinal gradient in the percentage change of urban $\mathrm{SO}_{2}$ concentration in Japan is found during 2000-2007, indicating that the decrease of urban $\mathrm{SO}_{2}$ is lower in areas close to the Asian continent. This implies that the transport of increasing $\mathrm{SO}_{2}$ from the Asian continent partially counteracts the local reduction of $\mathrm{SO}_{2}$ emission downwind. The aerosol optical depth (AOD) products of Moderate Resolu-
\end{abstract}

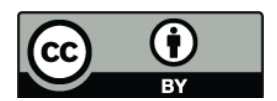

Correspondence to: $\mathrm{Z}$. Lu (zlu@anl.gov) tion Imaging Spectroradiometer (MODIS) are found to be highly correlated with the surface solar radiation (SSR) measurements in East Asia. Using MODIS AOD data as a surrogate of SSR, we found that China and East Asia excluding Japan underwent a continuous dimming after 2000, which is in line with the dramatic increase in $\mathrm{SO}_{2}$ emission in East Asia. The trends of AOD from both satellite retrievals and model over East Asia are also consistent with the trend of $\mathrm{SO}_{2}$ emission in China, especially during the second half of the year, when sulfur contributes the largest fraction of AOD. The arrested growth in $\mathrm{SO}_{2}$ emissions since 2006 is also reflected in the decreasing trends of $\mathrm{SO}_{2}$ and $\mathrm{SO}_{4}^{2-}$ concentrations, acid rain $\mathrm{pH}$ values and frequencies, and $\mathrm{AOD}$ over East Asia.

\section{Introduction}

Sulfur dioxide $\left(\mathrm{SO}_{2}\right)$ in the atmosphere is emitted from both anthropogenic and natural sources. In addition to adverse effects on human health, $\mathrm{SO}_{2}$ and its atmospheric products (e.g., sulfate, sulfuric acid) can affect the atmospheric environment from local to regional and global scales (e.g., acid deposition, direct and indirect radiative forcing). It is estimated that anthropogenic sources account for more than $70 \%$ of $\mathrm{SO}_{2}$ global emission, half of which are from fossil-fuel combustion (Whelpdale et al., 1996). The anthropogenic $\mathrm{SO}_{2}$ emission in China is of increasing concern because it contributed to about one-fourth of the global emission and more than $90 \%$ of East Asia emission since the 1990s (e.g.,

Published by Copernicus Publications on behalf of the European Geosciences Union. 
Streets et al., 2000, 2006a, 2008, 2009; Ohara et al., 2007). Also, the effect of $\mathrm{SO}_{2}$ emission in the Asian continent on the regional and global environment has been studied by using both chemical transport models (Aikawa et al., 2010; Lin et al., 2008; Osada et al., 2009) and intensive field experiments, e.g., ACE-Asia (Huebert et al., 2003), TRACE-P (Jacob et al., 2003), and INTEX-B (Singh et al., 2009), and most recently by using satellite observations directly (Lee et al., 2008; Li et al., 2010a; van Donkelaar et al., 2008). Taken together, the results of these studies strongly suggested that the generation of sulfur species was increasing over time in this region, and sulfur-containing air pollutants (e.g., sulfate) are transported long distances from the Asian continent to the Northwestern Pacific, North America, and the rest of the northern hemisphere. The prime motivation of this study is to support the latest National Aeronautics and Space Administration (NASA) field experiment on Arctic Research of the Composition of the Troposphere from Aircraft and Satellites (ARCTAS) (Jacob et al., 2010). Our study provides a foundation for understanding and quantifying present-day releases of $\mathrm{SO}_{2}$ and sulfate from the Asian continent, so that realistic simulations of the transport of sulfur species to the Arctic region can be made and compared with ARCTAS field and satellite observations.

The $\mathrm{SO}_{2}$ emission in China has changed dramatically since 2000. During the Chinese 10th Five-Year Plan period (2001-2005), the State Environmental Protection Administration (SEPA) - changed to the Ministry of Environmental Protection (MEP) in March 2008 - set a goal to reduce the national $\mathrm{SO}_{2}$ emission level in $2000(20 \mathrm{Tg} /$ year $)$ by $10 \%$ by the year 2005 (i.e., to $18.0 \mathrm{Tg} /$ year). However, this goal was not achieved. Due to the massive increase in fossil-fuel consumption resulting from rapid economic growth, the lag of the introduction of desulfurization equipment, and the low efficiency of the installed desulfurization devices, the national $\mathrm{SO}_{2}$ emission in 2005 actually rose to $25.5 \mathrm{Tg} /$ year, $42 \%$ higher than the goal. Furthermore, these $\mathrm{SO}_{2}$ emission values reported annually by the China MEP are believed to be underestimated due to the neglect of emission from rural industries and biofuels (Streets et al., 2003; Zhang et al., 2009a). Although there have been previous studies that reported estimates of $\mathrm{SO}_{2}$ emission from China (e.g., Streets et al., 2000; Ohara et al., 2007; Zhang et al., 2009a, and references therein), few of them focused on trends during the period after 2000. The Regional Emission Inventory in Asia (REAS) developed by Ohara et al. (2007) only presented historical $\mathrm{SO}_{2}$ emission in China up to 2003, and it was reported to overestimate the $\mathrm{SO}_{2}$ emission due to not reflecting the recent spread of desulfurization devices in China (Aikawa et al., 2010). Other studies such as Zhang et al. (2009a), Klimont et al. (2009), and Zhao et al. (2009) estimated $\mathrm{SO}_{2}$ emission either for a single year or without annual time series. In a rapidly developing country like China, new technologies are continuously coming into the market, causing dramatic changes in the technology distribution as well as the emission factor distribution in relevant sectors (Zhang et al., 2009a). Therefore, it is necessary to present the historical $\mathrm{SO}_{2}$ emission based on the dynamic technology penetration and the dramatic growth in activity rates after 2000 .

In this paper, we first present the change of $\mathrm{SO}_{2}$ emission in China since 2000 by using a technology-based methodology specifically for China. The $\mathrm{SO}_{2}$ emission data are then compared with a variety of official environmental statistics, ground-based measurements, satellite observations, and model results of sulfur related quantities over East Asia, such as $\mathrm{SO}_{2}$ and $\mathrm{SO}_{4}^{2-}$ concentrations, surface solar radiation (SSR), aerosol optical depth (AOD), etc., to investigate their consistency. The results are intended to provide a better understanding of the impact of $\mathrm{SO}_{2}$ emission in China across the East Asian region and the large increase in sulfur release and deposition that occurred between 2000 and 2006. We also indicate how these impacts changed after 2006.

\section{Method and data sets}

\subsection{Estimation of anthropogenic $\mathrm{SO}_{2}$ emission in China}

\subsubsection{General method}

In previous work, we developed a detailed technology-based methodology specifically for China to estimate the emission of various atmospheric pollutants in various time periods (Streets et al., 2006b; Zhang et al., 2007a, b, 2009a). In this study, we adopt the same approach. Emissions are estimated based on activity data for 31 provinces in mainland China. Hong Kong, Macao, and Taiwan are not included because data are not typically in available in the various governmental statistical reports and yearbooks in China. The emission sources are classified into four major sectors: power generation, industry, domestic, and transportation, including both fuel combustion and non-combustion sources. The provincial emission of $\mathrm{SO}_{2}\left(E_{i}\right)$ is estimated from the following equation:

$E_{i}=\sum_{j} \sum_{k} A_{i, j, k}\left[\sum_{m} X_{i, j, k, m} \mathrm{EF}_{i, j, k, m}\right]$

where $i, j, k, m$ represent the province (municipality, autonomous region), the economic sector, the fuel or product type, and the technology type for combustion and industrial processes, respectively. A represents the activity rate, such as fuel consumption or material production, and $X$ represents the fraction of fuel or production for a sector that is consumed by a specific technology. EF is the net emission factor, and for the fuel combustion sources it can be calculated by:

$\mathrm{EF}_{n}=2 \times S \times(1-\mathrm{SR}) \times\left(1-\eta_{n}\right)$

where $\eta_{n}$ is the removal efficiency of control technology $n$; $S$ and SR are the sulfur content of fuel and sulfur retention 
in ash, respectively. Based on this framework, we updated China's $\mathrm{SO}_{2}$ emission to the year 2008 with the most recent statistics available, including fuel consumption, flue-gas desulfurization (FGD) penetration, technology renewal, human activity, and so on. The $\mathrm{SO}_{2}$ emissions of other countries (e.g., Japan, South Korea) in East Asia are from a variety of published works, and they are discussed in detail in Sect. 3.2.

\subsubsection{Activity rates and emission factors}

Activity data for China during the period 2000-2008 were obtained from statistics published by a variety of government agencies. The fossil-fuel and biofuel consumption of stationary combustion sources by sector and by province were derived from the provincial energy balance tables of the China Energy Statistical Yearbook (CESY) (National Bureau of Statistics, 2000-2008a). It was reported that the statistical data of coal consumption in the province-by-province data of CESY may be underestimated, particularly during the period 1999-2003 (Akimoto et al., 2006). This was further supported by the modification of national energy balance tables of these years in CESY-2005 according to China's First National Economic Census. Here, we revised the provincial fuel consumption based on the changes in the national energy balance tables. As shown in Fig. 1, the coal consumption in China increased from 1271 to $2740 \mathrm{Mt}$ during 2000-2008, with an annual average increase rate of $10.1 \%$; power plants contributed about $65 \%$ of this increase. For non-combustion sources, industrial production levels by province were obtained from the China Industry Economy Statistical Yearbook (National Bureau of Statistics, 2000-2008b).

For on-road vehicle sources, we categorized vehicles into seven types, corresponding to the classification scheme in the USEPA's MOBILE emission factor model (Streets et al., 2006b), as modified for application to China (the so-called "MOBILE-CHINA" model, Fu et al., 2001). To be thorough in our estimation, we include both urban and rural vehicles in our calculation. The fuel consumption of each type was calculated as a product of the vehicle population, the annual average vehicle mileage traveled, and the fuel economy for each vehicle type. The vehicle populations by type were derived from the China Automotive Industry Yearbook (China Automotive Research Center, 2000-2008). The model has been reported to be suitable for extensive analysis on mobile source emissions in China as it is based on test results of the Chinese vehicle fleet (Fu et al., 2001; He et al., 2005). Details of the methodology have been described elsewhere (He et al., 2005). In China, diesel fuel is not only consumed in on-road vehicles, but also widely used in off-road mobile sources, such as locomotives, vessels, tractors, and agricultural and construction machinery. However, it is difficult to obtain detailed data on diesel use by equipment type in China, since this information is not available at provincial level. In this study, the method described in Zhang et

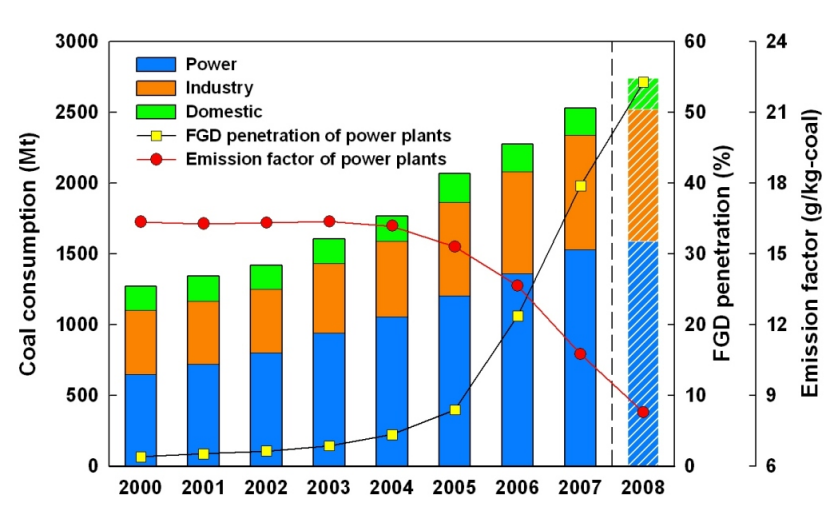

Fig. 1. Coal consumption by sector, average FGD penetration of power plants, and average emission factor of power plants in China during 2000-2008. The data for the year 2008 are extrapolated based on national fast-track statistics.

al. (2007a) was used to decompose the diesel consumption into different types of off-road sources. We first subtract the vehicular (on-road and rural vehicles) diesel consumption derived in our model from total diesel consumption (from CESY), and then allocate the remaining part to each off-road equipment type based on the shares reported by Yang (2001). At present, most of the provincial activity data are not available for year 2008. We therefore extrapolated activity rates based on some national fast-track statistics. If data were unavailable, they were assumed to remain the same as in year 2007.

Dynamic emission factors were used to reflect the dramatic changes in fuel property and technology penetration during 2000-2008. The sulfur contents $(S)$ of coal consumed by combustion sources in each province were derived from Streets et al. (2003), Ohara et al. (2007), Zhao et al. (2008, 2009), and Xu et al. (2009). The national average $S$ of coal in China was $1.08 \%$ and $1.02 \%$ in 2000 and 2005, respectively. We used interpolation values to represent $S$ in each year during 2000-2005, and assumed the sulfur contents did not vary after 2005 since no reliable data are available. The sulfur retention ratios (SR) were assumed to be 0.15 for power plants and $0.05-0.45$ for other sectors, depending on the process type, combustion technology, and coal type. The sulfur contents of oil products were determined from the national standards, which are $0.22 \%$ and $0.05 \%$ for diesel and gasoline, respectively (Zhao et al., 2008). Province-by-province FGD application rates of power plants were estimated by the ratio of average FGD installed capacity to average capacity of power plants in each year. Relevant data were obtained from the China MEP and the China Electric Power Yearbook (State Electricity Regulatory Commission, 20002008). FGD application rates can impact emission factors significantly. As shown in Fig. 1, the FGD penetration of power plants increased from 4\% in 2004 to $54 \%$ in 2008, and net emission factors decreased by $49 \%$, correspondingly. 


\subsection{Data sets of $\mathrm{SO}_{2}$ and $\mathrm{SO}_{4}^{2-}$ concentrations}

The annual $\mathrm{SO}_{2}$ concentrations, $\mathrm{pH}$ values, and frequencies of acid rain in Chinese cities are collected from a wide range of sources, including Environmental Bulletins of various cities and provinces, China Environment Yearbook, China Statistical Yearbook on Environment, China Statistical Yearbook for Regional Economy, etc. The $\mathrm{SO}_{2}$ concentration data of Japan are from the air pollution database system operated by the Environmental Information Center of the National Institute for Environmental Studies (NIES, http://www.nies.go.jp/igreen/index.html). In this work, the data from about 1000 Japanese sites that have continuous $\mathrm{SO}_{2}$ records between 2000 and 2007 are used. We also use the $\mathrm{SO}_{2}$ and $\mathrm{SO}_{4}^{2-}$ monitoring data reported annually by the Acid Deposition Monitoring Network in East Asia (EANET). EANET started its regular phase of operation on 1 January 2001, and it had included 50 sites in 13 countries by the end of 2007. Here, data from 13 sites ( 1 urban, 3 rural, and 9 remote) in Japan and South Korea are used (Network Center for EANET, 2001-2008).

The $\mathrm{SO}_{2}$ satellite data are from both the Scanning Imaging Absorption Spectrometer for Atmospheric Chartography (SCIAMACHY) aboard the European Space Agency's (ESA) Environmental Satellite (ENVISAT) (Bovensmann et al., 1999) and the Ozone Monitoring Instrument (OMI) aboard the NASA's Earth Observing System (EOS)/Aura satellite (Levelt et al., 2006). SCIAMACHY and OMI were launched in March 2002 and July 2004, respectively. Using the Differential Optical Absorption Spectroscopy (DOAS) method, the SCIAMACHY sensor retrieves atmospheric slant columns of $\mathrm{SO}_{2}$ from spectra Channel $2(310-405 \mathrm{~nm})$ in nadir viewing geometry, and the OMI sensor retrieves column $\mathrm{SO}_{2}$ amounts using UV radiation in the wavelength range of $311-315 \mathrm{~nm}$ (Krotkov et al., 2006, 2008). Then the slant column is converted to a vertical column using an appropriate air-mass factor (AMF). The value of AMF is dependent on the satellite viewing geometry, the $\mathrm{SO}_{2}$ vertical distribution, the reflectivity (albedo) of the earth's surface, the total column ozone, aerosols and clouds, etc. (Krotkov et al., 2008). For SCIAMACHY, we use the monthly level-3 product with grid cells of $0.25^{\circ} \times 0.25^{\circ}$ from the Support to Aviation Control Service (SACS, http://sacs.aeronomie.be/index.php), for which the AMF is pre-calculated with the radiative transfer model LIDORT for three different assumed plume heights $(1 \mathrm{~km}$, $6 \mathrm{~km}$, and $14 \mathrm{~km}$ above local ground level). For OMI, the planetary boundary layer (PBL) $\mathrm{SO}_{2}$ data in the $\mathrm{OMSO} 2$ Level-2G products were used, and they were acquired from NASA's Goddard Earth Sciences Data and Information Services Center (GES-DISC) at http://disc.sci.gsfc.nasa. gov/Aura/data-holdings/OMI/omso2g_v003.shtml. Daily retrievals were first filtered to remove data with large solar zenith angle $\left(>70^{\circ}\right)$, or relatively high radiative cloud fraction $(>0.3)$ and terrain height $(>1.5 \mathrm{~km})$, or anomalous scenes, and then averaged at $0.5^{\circ} \times 0.5^{\circ}$ resolution to reduce the noise (Nickolay Krotkov, personal communication). Annual mean $\mathrm{SO}_{2}$ column amounts were then calculated from the daily data for the years 2005-2008.

\subsection{Data sets of SSR and AOD}

It has been reported that solar radiation reaching the Earth's surface underwent a widespread decrease between the 1950s and 1980s, and an increase in the 1990s (Stanhill and Cohen, 2001; Wild et al., 2005). This so-called "dimming" and "brightening" was believed to be caused by changes in aerosol abundances, cloud characteristics, and aerosol optical properties, but not by any extraterrestrial changes in the amount of solar radiation incident on the planet or changes in the constituents of radiatively active gases (Wild, 2009). For East Asia, however, cloud cover changes cannot fully explain the SSR changes after the 1950s. Qian et al. (2006) reported concurrent decreases in both cloudiness and SSR over China between 1954 and 1994. Norris and Wild (2009) developed a technique to remove the effect of cloud cover variability on the all-sky SSR trends, and they found that cloud cover changes made negligible contributions to the SSR decline in China before the 1990s and only one-third of the trend over Japan during the 1990s. On the other hand, SSR changes over East Asia after the 1980s are in line with the changes in anthropogenic emission and consequent changes in AOD (Streets et al., 2006a, 2008, 2009). It suggests that changes in the mass and optical properties of anthropogenic aerosol are the most likely cause of SSR changes observed in East Asia (Wild, 2009). Hence, in this work, SSR observations are used as a surrogate of AOD monitoring data.

AOD is the degree to which aerosols prevent the transmission of light. It is defined as the integrated extinction coefficient over a vertical column of unit cross section, and the extinction coefficient is the fractional depletion of radiance per unit path length. To simplify the comparison, the solar irradiance $(I)$ change due to aerosols at a given wavelength is calculated by the classical equation (Streets et al., 2009):

$I / I_{0}=\exp (-\mathrm{AOD})$

where $I_{0}$ is the extraterrestrial (top-of-the-atmosphere) irradiance of the sun. On the basis of measurements and model simulations in China, Xia et al. (2007) found that an exponential function is suitable for the relationship between surface irradiance and AOD. Therefore, it is appropriate to set up the relationship between SSR observation and AOD using Eq. (3). It should be noted that Eq. (3) does not take into account the differences in the attenuation of solar radiation per unit AOD among different aerosol components (forcing efficiency). This means that the surface solar radiation trends may not follow the $\exp (-\mathrm{AOD})$ trends over a particular region if the aerosol composition changes significantly over time. This method is expected to be valid because 
the aerosol composition remains relatively stable on an annual basis over East Asia, and only normalized trends (see Sect. 2.5) are compared (Streets et al., 2009).

The SSR observation data used in this study are a subset of the data reported by Wild et al. (2009). For East Asia, allsky values of SSR measurements are taken from the Global Energy Balance Archive (GEBA) at the Swiss Federal Institute of Technology (ETH) Zurich (Gilgen et al., 1998), and the World Radiation Data Center (WRDC) of the Main Geophysical Observatory in St. Petersburg. Since the time period studied in the present work is from 2000 to 2008, we only include stations with continuous reliable records up to at least 2005. In all, data from 28 stations in four countries are used in this work: Japan (14 sites), China (7 sites), Mongolia (3 sites), and South Korea (4 sites).

AOD satellite retrievals are from the Moderate Resolution Imaging Spectroradiometer (MODIS) and Multi-angle Imaging Spectroradiometer (MISR), both of which were launched onboard NASA's EOS-Terra satellite in December 1999 and have been taking aerosol measurements since February 2000. The MODIS AOD retrieval is based on scene brightness over dark surfaces, using empirical relationships in the spectral variation in surface reflectivity (Remer et al., 2005). The AOD data have discontinuities in some mesh grid points, mainly in middle and high latitudes (i.e., bright land surfaces such as the desert and snow-covered surfaces), which were excluded in the analysis (Chin et al., 2004). The MISR instrument uses observed differences in the reflective properties of Earth's surface with nine viewing angles to retrieve AOD (Kahn et al., 2005). In this study, the monthly level-3 products of MODIS (version 5) and MISR (version 31) are used, and they were acquired using the NASA's GES-DISC Interactive Online Visualization and Analysis Infrastructure (Giovanni) (http://disc.sci.gsfc.nasa.gov/giovanni). Global coverage in the absence of clouds is obtained in one to two days for MODIS and in six to nine days for MISR. Horizontal resolutions are $1^{\circ} \times 1^{\circ}$ and $0.5^{\circ} \times 0.5^{\circ}$ for MODIS and MISR, respectively.

\subsection{Model simulations of sulfur and AOD}

Sulfur $\left(\mathrm{SO}_{2}+\mathrm{SO}_{4}^{2-}\right)$ simulation results from the Sulfur Transport and dEposition Model (STEM) for the period 2000 to 2008 are used to investigate the influences of changing emissions in East Asia on the surface concentrations of $\mathrm{SO}_{2}$ and $\mathrm{SO}_{4}^{2-}$. The $\mathrm{STEM}$ model is a regional-scale atmospheric chemistry transport model that has been used extensively to study aerosols and trace gases in Asia (Adhikary et al., 2007, 2008; Carmichael et al., 2009). The anthropogenic emission inventories used in the model are TRACE-P for 2001, INTEX-B for 2006 and an Olympic-Base inventory that was developed specifically for the Beijing Olympic Games period in 2008. Also, we have some multiple-year simulations using the same emissions, which are used to examine the impact of inter-annual meteorological variability on the sulfur trends over East Asia. The available model runs and the applied anthropogenic emission inventories are summarized in Table 1. The model was run on $60-\mathrm{km}$ horizontal grids. The meteorological fields used to drive the STEM model for 2001-2005 were based on MM5, and for the later years were based on the Weather Research and Forecasting Model (WRF).

For the purpose of comparing the effect of $\mathrm{SO}_{2}$ emission changes in China on the AOD over East Asia, we use results from the Goddard Chemistry Aerosol Radiation and Transport (GOCART) model (Chin et al., 2000, 2004), updated to GOCART c3.1 simulation for 2000-2007 (Chin et al., 2009) (available on Giovanni). The GOCART model simulates major tropospheric aerosol components, including sulfate, dust, black carbon (BC), organic carbon (OC), and sea salt, as well as the precursor gaseous species of $\mathrm{SO}_{2}$ and dimethylsulfide (DMS). It uses the assimilated meteorological fields of the Goddard Earth Observing System Data Assimilation System (GEOS DAS) version 4, with a spatial resolution of $1^{\circ}$ latitude by $1.25^{\circ}$ longitude, and 30 vertical sigma layers. Physical processes in the model include emission, advection, convection, boundary layer mixing, wet deposition, dry deposition, gravitational settling, and hygroscopic growth of aerosols. Chemical processes include gas- and aqueousphase reactions that convert DMS and $\mathrm{SO}_{2}$ to sulfate (Chin et al., 2004, 2009). The annual anthropogenic emissions of BC and OC between 2000 and 2006 are based on recent inventories (Bond et al., 2004; Streets et al., 2006b, 2009). Furthermore, the model also accounts for time-varying emissions from aircraft and ships, biomass burning, biogenic, oceanic and volcanic sources, wind-blown dust, sea salt and so on, all of which are described in detail by Chin et al. (2009). AOD is determined from the dry mass concentrations and mass extinction efficiencies. The mass extinction efficiencies are calculated from Mie theory on the basis of size distributions, refractive indices, and hygroscopic properties of individual aerosol types. Single-mode, lognormal size distributions for sulfate, BC, and OC aerosols, as well as for each dust and sea salt size bin are assumed in the model. All aerosol particles are treated as external mixtures due to difficulties in quantifying the mixing state and the resulting optical properties (Chin et al., 2004, 2009).

\subsection{Trends comparison}

For ease of comparison between the trends of multifarious data sets, all the data sets are normalized based on the method introduced in our previous work (Streets et al., 2009), i.e.:

$x_{i, j}^{\prime}=\left(x_{i, j}-\overline{x_{j}}\right) / \sigma_{j}$

where $\overline{x_{j}}$ is the average value and $\sigma_{j}$ is the standard deviation of data set $j$, and $x_{i, j}^{\prime}$ is the $i$ th normalized value of data set $j\left(x_{i, j}\right)$. 
Table 1. Summary of the available STEM model runs and the applied anthropogenic emission inventories.

\begin{tabular}{lllll}
\hline & 2001-2005 $^{\mathrm{a}}$ & 2006 & 2007 & 2008 \\
\hline Annual & TRACE-P $^{\mathrm{b}}$ & - & - & - \\
April & TRACE-P $^{\mathrm{b}}$ & INTEX-B $^{\mathrm{c}}$ & - & ARCTAS $^{\mathrm{d}}$ \\
July & TRACE-P $^{\mathrm{b}}$ & - & - & ARCTAS $^{\mathrm{d}}$ Olympic-Base $^{\mathrm{e}}$ \\
August & TRACE-P $^{\mathrm{b}}$ & - & Olympic-Base $^{\mathrm{e}}$ & Olympic-Base $^{\mathrm{C}}$ \\
\hline
\end{tabular}

\footnotetext{
a Only 8-month simulation (January to August) is available for the year 2005.

$\mathrm{b}$ The target year for the TRACE-P inventory is 2001 .

c The target year for the INTEX-B inventory is 2006.

$\mathrm{d}$ The emission within the Asian continent of the ARCTAS inventory is essentially the same as that of the INTEX-B inventory.

e The Olympic-Base inventory specifically targets the Beijing Olympic Games period in 2008. The emission estimates for China are improved for the Beijing area and updated based on the INTEX-B inventory.
}

\section{$3 \mathrm{SO}_{2}$ emission in East Asia after 2000}

\subsection{Anthropogenic $\mathrm{SO}_{2}$ emission in China after 2000}

\subsubsection{Trend and distribution of the emissions}

Figure 2a shows the annual trend of $\mathrm{SO}_{2}$ emission in China after 2000 , and emissions by province and by sector are presented in Table 2. Compared to the relatively stable or decreasing trend during 1995-1999 (Ohara et al., 2007; Streets et al., 2000, 2006a, 2008), we estimate that the $\mathrm{SO}_{2}$ emission in China increased by $53 \%$, from $21.7 \mathrm{Tg}$ in 2000 to $33.2 \mathrm{Tg}$ in 2006, with an annual growth rate of $7.3 \%$. This growth rate is in good agreement with annual growth rates of $6.3 \%-9.9 \%$ estimated by other researchers (Klimont et al., 2009; Ohara et al., 2007; Zhang et al., 2009a), and of 6.2\%-9.6\% derived from satellite constraints (van Donkelaar et al., 2008). This dramatic change was driven by the rapid increase of fossilfuel consumption (78\% growth in total energy consumption) due to the economic boom (99\% growth in GDP) during this period. Although the GDP and the total energy consumption in China were still increasing after 2006, the national $\mathrm{SO}_{2}$ emissions began to decrease, due to the application of FGD technology and the phase-out of small, high-emitting power generation units. In 2006 China's MEP reaffirmed its commitment to reducing $\mathrm{SO}_{2}$ emissions. It resolved in its 11th Five-Year Plan (2006-2010) to cut the national $\mathrm{SO}_{2}$ emissions by $10 \%$ (i.e., to $22.9 \mathrm{Tg}$ in 2010 ), relative to the 2005 level. To achieve this goal, emission reduction requirements were to be strictly enforced. As a result, FGD devices began to be widely installed in coal-fired power plants in China (Xu et al., 2009). By the end of 2008, the FGD penetration had risen to $60 \%$, which is responsible for an estimated reduction of $13.3 \mathrm{Tg} \mathrm{SO}$ in that year. However, it should be noted that the actual operation of FGD equipment is unknown, which could impact the $\mathrm{SO}_{2}$ emission significantly (see emission factor changes in Fig. 1) and certainly increases the level of uncertainty in emission after 2005. To motivate the use of FGD equipments, multiple measures have been taken by

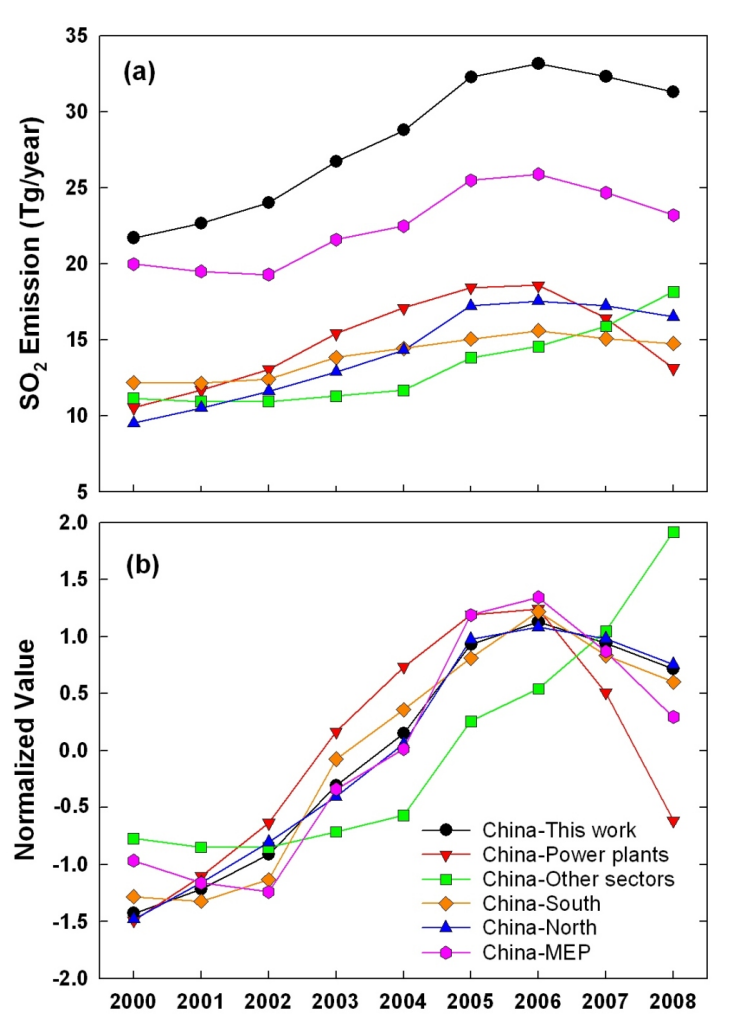

Fig. 2. Trends of $\mathrm{SO}_{2}$ emission in China, 2000-2008. (a) $\mathrm{SO}_{2}$ emission; (b) Normalized values of $\mathrm{SO}_{2}$ emission.

China MEP since 1 July 2007, including the installation of the continuous monitoring systems in all power plants with FGD devices, and the implementation of a premium/penalty scheme of electricity price that varies with the FGD's operation rate. These measures have been reported to be effective. For example, the coastal province of Jiangsu realized an operation rate of $97 \%$ in July 2007 (Xu et al., 2009). Additionally, recent developments in $\mathrm{SO}_{2}$ satellite retrievals may be able to constrain the $\mathrm{SO}_{2}$ emission values or even the FGD 
Table 2. $\mathrm{SO}_{2}$ emission in China by province and by sector in 2000, 2004, and 2007 (unit: Gg/year) ${ }^{\mathrm{a}}$.

\begin{tabular}{|c|c|c|c|c|c|c|c|c|c|c|c|c|}
\hline \multirow[t]{2}{*}{ Province } & \multicolumn{4}{|c|}{2000} & \multicolumn{4}{|c|}{2004} & \multicolumn{4}{|c|}{2007} \\
\hline & $\mathrm{PO}$ & IN & DO & TR & $\mathrm{PO}$ & IN & DO & TR & $\mathrm{PO}$ & IN & DO & TR \\
\hline Anhui & 191 & 295 & 49 & 3 & 284 & 247 & 55 & 4 & 239 & 263 & 43 & 6 \\
\hline Beijing & 120 & 77 & 54 & 2 & 113 & 60 & 55 & 4 & 58 & 69 & 61 & 6 \\
\hline Chongqing & 127 & 753 & 151 & 1 & 258 & 494 & 172 & 1 & 286 & 623 & 177 & 2 \\
\hline Fujian & 133 & 144 & 22 & 1 & 166 & 132 & 15 & 2 & 165 & 235 & 25 & 4 \\
\hline Gansu & 95 & 83 & 38 & 1 & 214 & 82 & 45 & 1 & 224 & 105 & 53 & 2 \\
\hline Guangdong & 615 & 319 & 24 & 6 & 829 & 290 & 20 & 11 & 722 & 421 & 18 & 16 \\
\hline Guangxi & 263 & 469 & 18 & 1 & 441 & 472 & 22 & 2 & 380 & 596 & 41 & 3 \\
\hline Guizhou & 405 & 235 & 345 & 1 & 971 & 580 & 484 & 1 & 1095 & 776 & 486 & 2 \\
\hline Hainan & 22 & 11 & 3 & 0 & 35 & 31 & 3 & 1 & 50 & 12 & 0 & 1 \\
\hline Hebei & 750 & 523 & 212 & 5 & 1287 & 773 & 244 & 8 & 1100 & 1162 & 207 & 12 \\
\hline Heilongjiang & 154 & 60 & 8 & 2 & 178 & 37 & 10 & 3 & 213 & 83 & 18 & 4 \\
\hline Henan & 540 & 335 & 105 & 5 & 1184 & 232 & 108 & 7 & 1073 & 1033 & 159 & 10 \\
\hline Hubei & 293 & 1004 & 258 & 2 & 479 & 749 & 119 & 3 & 470 & 723 & 145 & 5 \\
\hline Hunan & 200 & 219 & 82 & 2 & 422 & 254 & 73 & 3 & 270 & 760 & 158 & 4 \\
\hline Inner Mongolia & 437 & 248 & 58 & 2 & 701 & 237 & 156 & 3 & 844 & 237 & 133 & 4 \\
\hline Jiangsu & 815 & 376 & 42 & 3 & 1110 & 478 & 29 & 6 & 963 & 624 & 31 & 10 \\
\hline Jiangxi & 166 & 141 & 27 & 1 & 391 & 163 & 33 & 2 & 322 & 255 & 36 & 3 \\
\hline Jilin & 185 & 102 & 44 & 2 & 215 & 84 & 44 & 2 & 219 & 143 & 52 & 3 \\
\hline Liaoning & 613 & 330 & 91 & 3 & 820 & 288 & 79 & 4 & 928 & 388 & 88 & 6 \\
\hline Ningxia & 87 & 65 & 16 & 0 & 272 & 55 & 21 & 1 & 368 & 145 & 20 & 1 \\
\hline Qinghai & 9 & 13 & 6 & 0 & 18 & 10 & 5 & 0 & 20 & 16 & 5 & 1 \\
\hline Shaanxi & 386 & 160 & 68 & 1 & 649 & 152 & 47 & 2 & 644 & 343 & 68 & 3 \\
\hline Shandong & 803 & 510 & 178 & 6 & 2167 & 1001 & 130 & 10 & 2374 & 1773 & 211 & 15 \\
\hline Shanghai & 401 & 134 & 23 & 1 & 453 & 113 & 24 & 2 & 399 & 115 & 22 & 3 \\
\hline Shanxi & 632 & 365 & 138 & 2 & 1173 & 394 & 193 & 3 & 1020 & 544 & 169 & 5 \\
\hline Sichuan & 800 & 737 & 265 & 2 & 867 & 765 & 245 & 4 & 450 & 598 & 156 & 6 \\
\hline Tianjin & 191 & 121 & 41 & 1 & 263 & 81 & 26 & 2 & 198 & 100 & 23 & 2 \\
\hline Xinjiang & 182 & 126 & 116 & 1 & 217 & 86 & 89 & 2 & 285 & 146 & 43 & 3 \\
\hline Yunnan & 81 & 84 & 49 & 2 & 117 & 127 & 85 & 3 & 295 & 283 & 75 & 5 \\
\hline Zhejiang & 854 & 479 & 41 & 2 & 804 & 470 & 11 & 6 & 753 & 432 & 14 & 10 \\
\hline Total & 10553 & 8518 & 2572 & 64 & 17097 & 8936 & 2642 & 104 & 16428 & 13000 & 2737 & 158 \\
\hline Percentage $(\%)$ & 48.6 & 39.2 & 11.8 & 0.3 & 59.4 & 31.1 & 9.2 & 0.4 & 50.8 & 40.2 & 8.5 & 0.5 \\
\hline All Sectors & \multicolumn{4}{|c|}{21707} & \multicolumn{4}{|c|}{28780} & \multicolumn{4}{|c|}{32323} \\
\hline
\end{tabular}

a PO: power plants; IN: industry; DO: domestic; TR: transportation.

operation of large point sources (LPS) to verify $\mathrm{SO}_{2}$ emission in the future (Li et al., 2010b).

Figure 2a also shows the $\mathrm{SO}_{2}$ emission of China by sector (power and other) and by geographical region (north and south, see Fig. 3), and the normalized values of all these data sets are displayed in Fig. 2b. Power plants are the main sources of $\mathrm{SO}_{2}$, contributing more than $50 \%$ to the total emission. Compared to a $31 \%$ increase in emissions in other sectors, $\mathrm{SO}_{2}$ emission from power plants increased by $76 \%$, from $10.6 \mathrm{Tg}$ in 2000 to $18.6 \mathrm{Tg}$ in 2006 , which can be viewed in the context of a $116 \%$ increase of total thermal-based electricity generation during the same period. The trend of $\mathrm{SO}_{2}$ emission from the power sector is in good agreement with the national emission estimate (Fig. $2 \mathrm{~b}, R=0.95$ ), confirming that $\mathrm{SO}_{2}$ emission from power plants dominates the national $\mathrm{SO}_{2}$ emission. In particular, because of the decrease of power sector emission resulting from increasing FGD penetration, national $\mathrm{SO}_{2}$ emission declined after 2006, despite the continuously increasing emission from other sectors.

Geographically, the emissions from both north and south China are highly correlated with the total emission $(R>$ 0.99 ), implying that the change of $\mathrm{SO}_{2}$ emission is nationwide. However, the extent of the increment is quite different geographically. From 2000 to 2006, $\mathrm{SO}_{2}$ emission from north China increased by $85 \%$, whereas that from south China increased by only $28 \%$. This result mirrors the fact that more power plants were constructed in north China (e.g., Inner Mongolia, Shandong, Henan, and Hebei provinces), and some of those in Inner Mongolia have been identified by $\mathrm{NO}_{\mathrm{x}}$ 


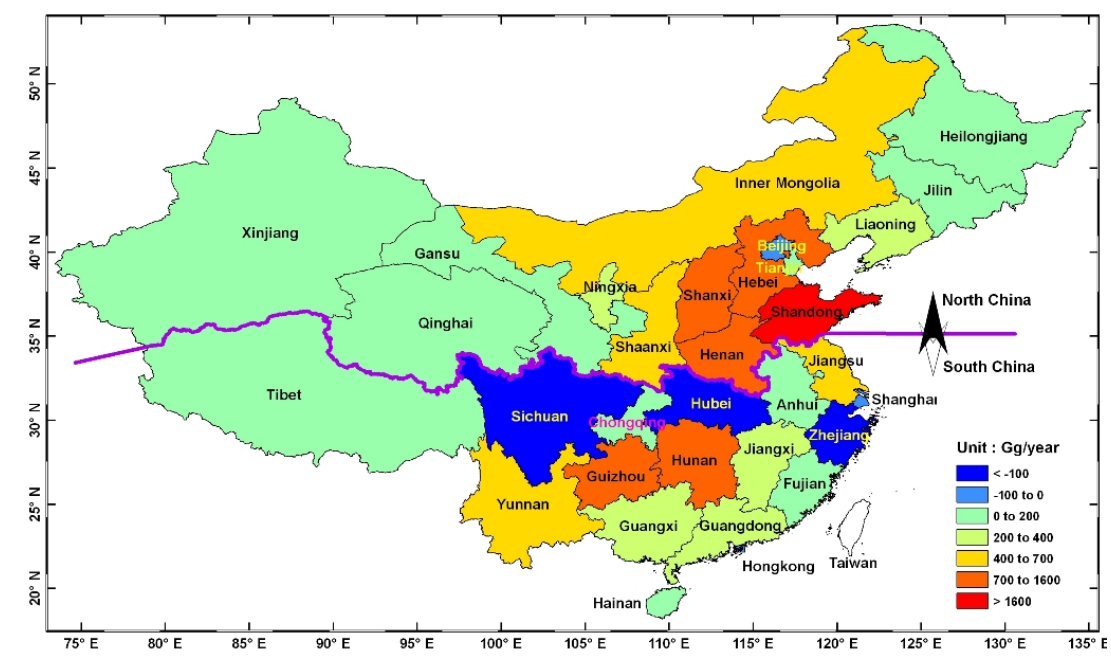

Fig. 3. Provincial change of $\mathrm{SO}_{2}$ emission in China between 2000 and 2006. Purple solid line indicates the dividing line of north and south China.

and $\mathrm{SO}_{2}$ observations of OMI aboard NASA's Aura satellite (Li et al., 2010b; Zhang et al., 2009b). Figure 3 shows the change of $\mathrm{SO}_{2}$ emission in China by province between 2000 and 2006. Generally, increments are highest in the eastern central China (e.g. Shandong, Hebei, and Henan provinces). Since this area is directly to the windward of Japan and South Korea, the dramatic change of $\mathrm{SO}_{2}$ emission after 2000 may influence $\mathrm{SO}_{2}, \mathrm{SO}_{4}^{2-}$ and AOD not only in China but also in other parts of East Asia, and this will be discussed further in the following sections.

\subsubsection{Comparison with previous studies}

Table 3 compares the $\mathrm{SO}_{2}$ emission estimated in this study to other works. Our estimates agree well with those reported by the China MEP (Ministry of Environmental Protection, 2009) (Fig. 2a, $R=0.96$ ), but are about $10-30 \%$ higher, which may be caused by the neglect of $\mathrm{SO}_{2}$ emission from rural industries and biofuels in the China MEP inventory (Streets et al., 2003; Zhang et al., 2009a). Besides total emissions, the trends of the two inventories are also similar at sector levels: a $76 \%$ increase of $\mathrm{SO}_{2}$ emission was estimated in the power sector in this study during 2000-2006, while MEP presented a $78 \%$ increase. For TRACE-P (Streets et al., 2003) in 2000, the differences are mainly attributed to the improvements of methodology (Zhang et al., 2009a); and for INTEX-B (Zhang et al., 2009a) in 2006, differences are attributed to the extrapolated activity rates from 2004 data in the INTEX-B data, which were lower than the actual data reported in CESY. Our estimates are slightly lower than GAINS (Klimont et al., 2009), and significantly lower than REAS (Ohara et al., 2007). This might be caused by a combined effect of the different amounts and distribution of fuel consumption between sectors and the implied emission fac- tor assumptions (Klimont et al., 2009). For emissions from power plants, estimates from different studies are similar, as the uncertainties of activity data and emission factors are relatively small. Our results are in good agreement with those of Zhao et al. (2008) for years before 2003, which presented a unit-based, bottom-up power plant emission inventory for China. The discrepancies after 2003 are attributed to the differences in coal consumption and FGD application rates. For example, total coal consumption and average FGD penetration in power plants in 2005 in the work of Zhao et al. (2008) are $1070 \mathrm{Mt}$ and $13 \%$, whereas those used in the present work are $1205 \mathrm{Mt}$ and $8 \%$, respectively. This also caused the national total emission estimated by Zhao et al. (2009) to be lower than this work. Recently, Aikawa et al. (2010) compared the measured sulfate $\left(\mathrm{SO}_{4}^{2-}\right)$ concentration with simulation results from a regional chemical transport model (CMAQ) at multiple sites over the East Asia Pacific Rim region. The $\mathrm{SO}_{2}$ emissions used in the model were prepared based on both the REAS and the China MEP inventories. Their comparisons suggest that the REAS inventory overestimates, whereas the China MEP inventory underestimates the $\mathrm{SO}_{2}$ emission from China. Our results fall midway between these two estimates.

\section{2 $\mathrm{SO}_{2}$ emission in Japan and South Korea after 2000}

Before discussing the relationship between $\mathrm{SO}_{2}$ emission in China and sulfur related quantities over East Asia, we first examine the $\mathrm{SO}_{2}$ emission changes in South Korea and Japan during the same time period. As shown in Fig. 4, anthropogenic $\mathrm{SO}_{2}$ data of South Korea from the Korea National Institute of Environmental Research (NIER, 2008) show a steady decreasing trend after 2000. At present, official emission inventory data in Japan are not available for comparison. 
Table 3. Comparison of $\mathrm{SO}_{2}$ emission estimates for China, 2000-2008 (unit: Tg/year).

\begin{tabular}{|c|c|c|c|c|c|c|c|c|c|}
\hline & 2000 & 2001 & 2002 & 2003 & 2004 & 2005 & 2006 & 2007 & 2008 \\
\hline \multicolumn{10}{|l|}{ Total Emission } \\
\hline China MEP & 20.0 & 19.5 & 19.3 & 21.6 & 22.5 & 25.5 & 25.9 & 24.7 & 23.2 \\
\hline TRACE-P, Streets et al. (2003) & 20.4 & & & & & & & & \\
\hline REAS, Ohara et al. (2007) & 27.6 & 29.3 & 31.9 & 36.6 & & & & & \\
\hline INTEX-B, Zhang et al. (2009a) & & 22.9 & & & & & 31.0 & & \\
\hline GAINS, Klimont et al. (2009) & 23.2 & & & & & 34.4 & & & \\
\hline Zhao et al. (2009) & & & & & & 30.7 & & & \\
\hline This work & 21.7 & 22.7 & 24.0 & 26.7 & 28.8 & 32.3 & 33.2 & 32.3 & 31.3 \\
\hline \multicolumn{10}{|l|}{ Emission from Power Plants } \\
\hline China MEP & 6.5 & 6.5 & 6.7 & 8.3 & 9.3 & 11.1 & 11.6 & 10.9 & 9.3 \\
\hline TRACE-P, Streets et al. (2003) & 10.0 & & & & & & & & \\
\hline REAS, Ohara et al. (2007) & 10.6 & & & & & & & & \\
\hline INTEX-B, Zhang et al. (2009a) & & 12.3 & & & & & 18.3 & & \\
\hline GAINS, Klimont et al. (2009) & 12.9 & & & & & 19.4 & & & \\
\hline Zhao et al. (2008) & 11.0 & 11.7 & 12.7 & 13.9 & 15.3 & 16.1 & & & \\
\hline This work & 10.6 & 11.7 & 13.1 & 15.4 & 17.1 & 18.4 & 18.6 & 16.4 & 13.1 \\
\hline
\end{tabular}

Kannari et al. (2007) developed a high temporal and spatial resolution inventory for Japan, but its target year was 2000. REAS developed by Ohara et al. (2007) is the first inventory to integrate historical, present, and future emission in Asia. However, its historical emission only covers the period from 1980 to 2003. Using the REAS's projected 2010 emission under the PFC (policy failure case) scenario, $\mathrm{SO}_{2}$ emissions in Japan between 2004 and 2007 are linearly interpolated and displayed in Fig. 4. Similar to South Korea, the estimated $\mathrm{SO}_{2}$ emission in Japan also slowly decreased. The slow decline and relatively low level of emissions is consistent with Japan having reached somewhere near the maximum application of currently available air quality control measures (Wild et al., 2009). This can be also confirmed by the slowly decreasing trend of $\mathrm{SO}_{2}$ emission from LPS, which is reported every three years by the Ministry of Environment of the Government of Japan (MOE, 2006), as shown in Fig. 4.

In Japan, volcanoes are another major source of $\mathrm{SO}_{2}$. It has been reported that the total emission of the six volcanoes in Japan is $\sim 1.2 \mathrm{Tg} \mathrm{SO}_{2}$ /year, whereas the domestic anthropogenic emission is only $\sim 1.0 \mathrm{Tg} /$ year (Fujita, 1990). Thus the $\mathrm{SO}_{2}$ released by volcanoes also needs to be included in any study of sulfur in East Asia. The most recent large eruption occurred at the Miyakejima volcano on 27 June 2000, and its intensive $\mathrm{SO}_{2}$ emission has been reported to impact the precipitation chemistry in Japan (An et al., 2003; Fujita et al., 2003; Kajino et al., 2004; Kitayama et al., 2008, 2010; Okuda et al., 2005). In this study, quantification of the volcanic $\mathrm{SO}_{2}$ emission in Japan is derived from the emission inventory developed by Diehl et al. (2010) (Fig. 4). This inventory takes into account both the quasi-continuously erupting volcanoes and the sporadically erupting volcanoes and

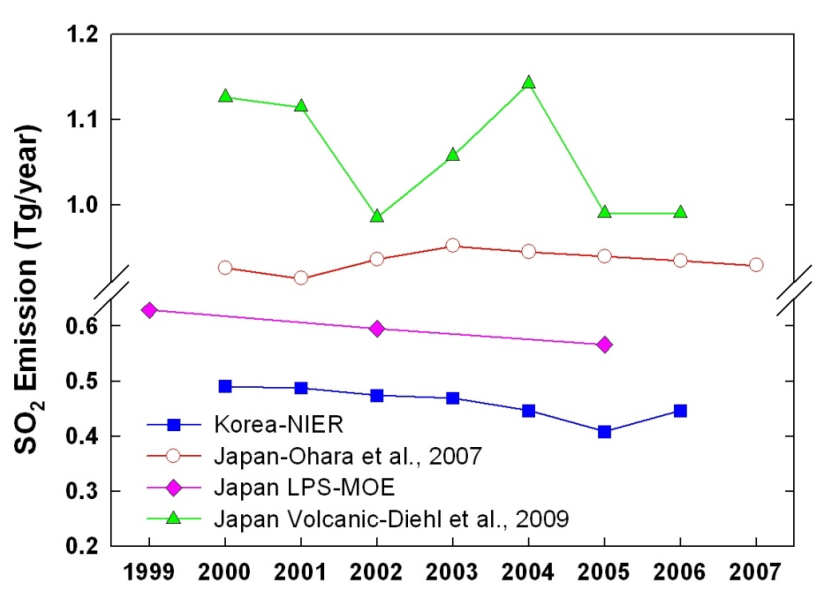

Fig. 4. Trends of $\mathrm{SO}_{2}$ emission in Japan and South Korea.

has already been applied in our previous work (Streets et al., 2009) and modeling studies (Chin et al., 2000, 2009) to estimate the contribution of volcanic $\mathrm{SO}_{2}$ to AOD globally. For $\mathrm{SO}_{2}$ emission from continuously degassing volcanoes, a constant global emission rate of $9.6 \mathrm{Tg} \mathrm{SO}_{2} /$ year is assumed (Andres and Kasgnoc, 1998). $\mathrm{SO}_{2}$ emissions of sporadically erupting volcanoes are mainly estimated from Volcanic Explosivity Index (VEI) data (Newhall and Self, 1982; Schnetzler et al., 1997) provided by the Global Volcanism Program (GVP) of the Smithsonian Institution (Siebert and Simkin, 2002). In addition, other data sources for some volcanoes are incorporated, such as satellite observations from the Total Ozone Mapping Spectrometer (TOMS) and the OMI (Carn et al., 2008; Krotkov et al., 2006) and measurements from the 
Correlation Spectrometer (COSPEC) near the volcano (e.g., for Miyakejima, Kazahaya et al., 2004). Figure 4 shows the trend in volcanic emissions in the Japan region from Diehl et al. (2010). Although there is some variability of volcanic emissions from 2000 to 2006 - probably associated with Miyakejima - the variation is quite small ( $\pm 8 \%$ of the average value of $1.1 \mathrm{Tg} /$ year), showing a small decreasing tendency during this period. In combination, Fig. 2 and Fig. 4 indicate that China is by far the dominant source of sulfur emission in the East Asia region.

\section{Comparison of $\mathrm{SO}_{2}$ emission, $\mathrm{SO}_{2}$ concentration, and $\mathrm{SO}_{4}^{2-}$ concentration}

\subsection{Correlations between $\mathrm{SO}_{2}$ emission and $\mathrm{SO}_{2}$ con- centration in China}

Figure 5 compares the change of $\mathrm{SO}_{2}$ emission (by province) and $\mathrm{SO}_{2}$ concentration (by major cities) in China from 2000 to 2006 (Fig. 5a) and 2006 to 2008 (Fig. 5b). The chromatic difference in each province represents the percentage $\mathrm{SO}_{2}$ emission change of that province, while that in each city represents its percentage $\mathrm{SO}_{2}$ concentration change. Due to the implementation of the revised Air Pollution Prevention and Control Law (APPCL) in 2000 and the relatively high $\mathrm{SO}_{2}$ ambient level before 2000, the $\mathrm{SO}_{2}$ concentrations in some big cities (e.g., municipalities, provincial capitals, and capitals of autonomous regions) decreased dramatically during 2000-2006 (Fig. 5a). However, the majority of cities still show a trend of increasing annual $\mathrm{SO}_{2}$ concentration, which is generally consistent with the $\mathrm{SO}_{2}$ emission increase during the same period. This result confirms the fact that $\mathrm{SO}_{2}$ is a primary air pollutant with a relatively short lifetime, and its concentration broadly reflects the emission level of its surrounding area. For the period between 2006 and 2008, a nationwide decrease in $\mathrm{SO}_{2}$ concentration also agrees well with the national emission decrease.

The $\mathrm{SO}_{2}$ change in China after 2000 can be seen even more clearly by using the satellite observations (Fig. 6). As shown in Fig. 6a and Fig. 6b, a substantial increase in the yearly average of boundary layer $\mathrm{SO}_{2}$ is observed by SCIAMACHY retrievals from 2004 to 2007 , and by OMI retrievals from 2005 to 2007. Especially in some areas of east central China (e.g., Inner Mongolia, Shandong, Hebei, Shanxi, and Henan provinces), the increments are larger than $0.3 \mathrm{DU}$. These increases are consistent with the total $\mathrm{SO}_{2}$ column changes predicted by the GOCART model (Fig. 6e and Fig. 6f). The discrepancy between satellite boundary layer $\mathrm{SO}_{2}$ and GOCART total column $\mathrm{SO}_{2}$ over southeastern Japan (i.e., in the region of the Miyakejima volcano) may be attributed to the assumptions of vertical profiles and AMF used in the SCIAMACHY and OMI PBL products, which may not reveal the volcanic emissions. It is reasonable to infer that the increase of $\mathrm{SO}_{2}$ over east central China is caused

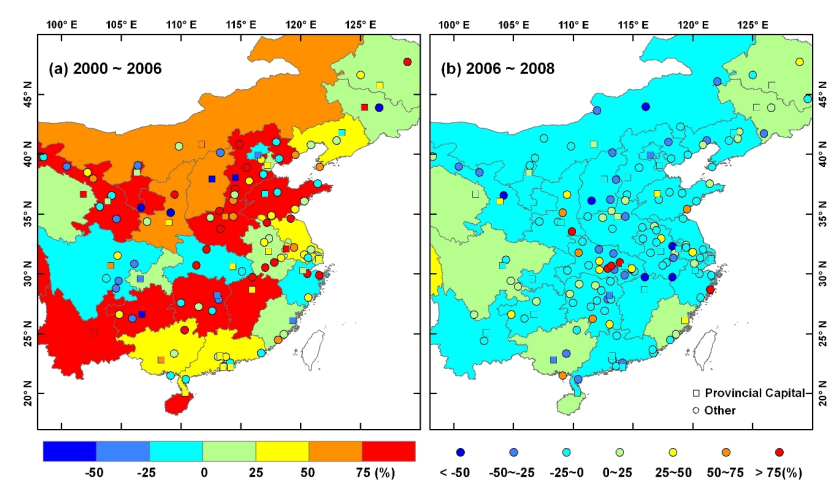

Fig. 5. Comparison of the percentage change of $\mathrm{SO}_{2}$ emission (provinces) and $\mathrm{SO}_{2}$ concentration (cities) in China: (a) from 2000 to 2006, and (b) from 2006 to 2008. Squares represent provincial capitals, municipalities, and capitals of autonomous regions.

by the increase of anthropogenic activities in these areas, and this is further confirmed by the column $\mathrm{SO}_{2}$ decrease in nearly the same areas from 2007 to 2008 (Fig. 6c, d). To improve air quality during the Beijing 2008 Olympic and Paralympic Games, more than 200 long-term emission reduction measures were carried out. Furthermore, to reduce pollutant emissions in Beijing after July 2008, the Chinese government implemented a series of short-term measures on large industrial sources and traffic, including reducing power plant emissions by $30 \%$ from levels in June, suspending the operation of heavily polluting factories, banning motor vehicles that failed to meet Euro I standards for exhaust emissions, restricting vehicles with even and odd-numbered license plants on alternate days, etc. These control measures were not only applied in Beijing but also extended to surrounding areas (e.g., Tianjin municipality, Inner Mongolia autonomous region, Hebei, Shanxi, and Shandong provinces). Emissions from these regions have been reported to significantly impact Beijing's air quality during the summertime (Streets et al., 2007; Wang et al., 2008). Therefore, in addition to the wide installation of FGD devices in coal-fired power plants, as discussed in Sect. 3.1.1, the nationwide decrease in $\mathrm{SO}_{2}$ boundary layer columns in 2008 can be partially attributed to a reduction in anthropogenic activities. Similar changes of $\mathrm{SO}_{2}$ columns before and after the Olympic Games have also been observed by the OMI instrument in Beijing and surrounding provinces in other studies ( $\mathrm{Li}$ et al., 2010b; Witte et al., 2009).

Figure 7a presents a comparison of inter-annual trends of normalized $\mathrm{SO}_{2}$ emissions and the simulated total sulfur concentrations $\left(\mathrm{SO}_{2}+\mathrm{SO}_{4}^{2-}\right.$, expressed as $\mathrm{SO}_{2}$, from the STEM model) averaged over China. A similar figure presenting the inter-annual trends of normalized ratios between north and south China is shown in Fig. 7b (see Fig. 3 for the definitions of north and south China). The $\mathrm{SO}_{2}$ emissions and the north-to-south ratios of emissions in 2008 are targeting 


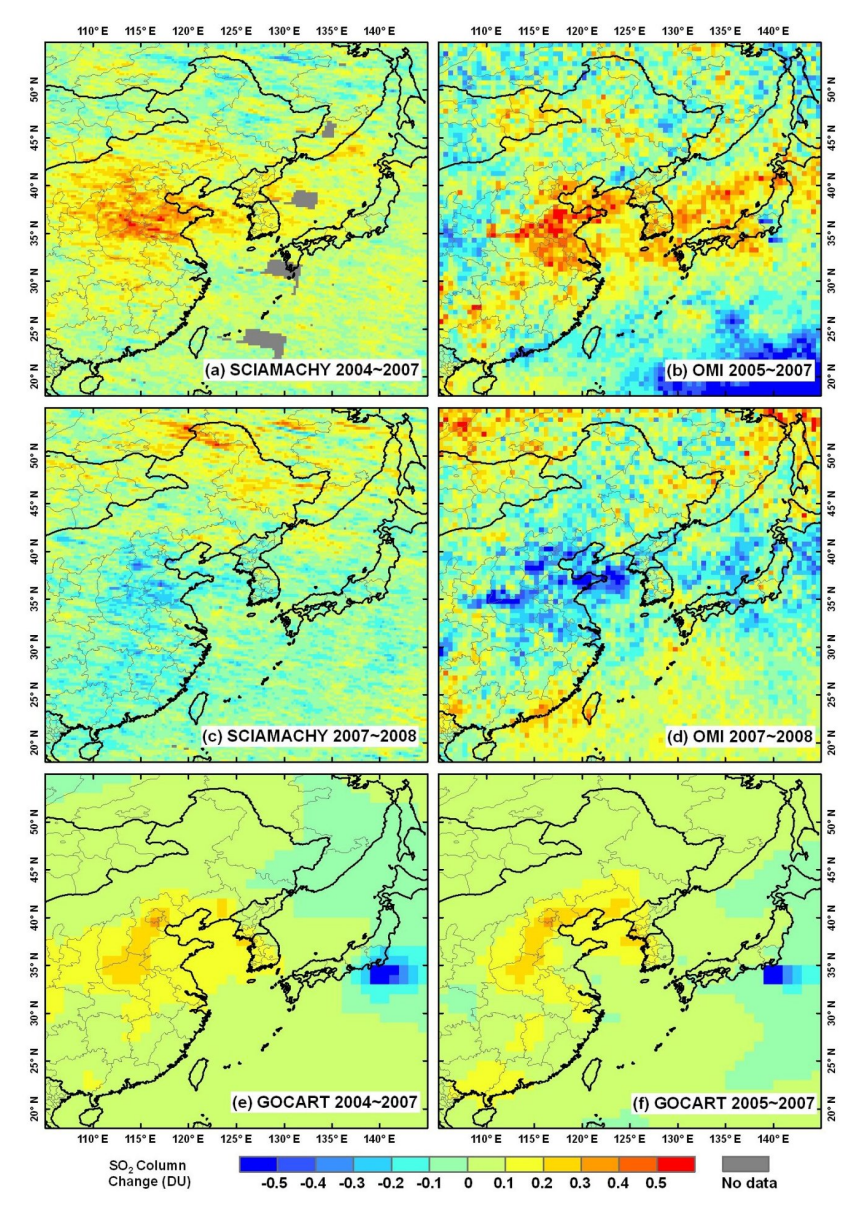

Fig. 6. Differences in annual $\mathrm{SO}_{2}$ vertical columns of boundary layer from satellite retrievals: (a) SCIAMACHY, 2004-2007, (b) OMI, 2005-2007, (c) SCIAMACHY, 2007-2008, (d) OMI, 20072008, and total $\mathrm{SO}_{2}$ columns predicted by the GOCART model: (e) GOCART, 2004-2007, (f) GOCART, 2005-2007.

the Olympic-Base inventory, which was used for the STEM model run of July and August 2008. In general, the simulated total sulfur concentrations mirror the changing $\mathrm{SO}_{2}$ emissions in China. Following the trend of $\mathrm{SO}_{2}$ emission, the total sulfur increased from 2001 to 2006 and dropped down dramatically after 2006. The modeled ratios of total sulfur between north and south China in different years also agree with the geographical change of $\mathrm{SO}_{2}$ emissions in both parts of China. It is worth noting that from 2000 to 2006, the $\mathrm{SO}_{2}$ emission in north China increased faster than that in south China, as discussed in Sect. 3.1.1. However, it seems that in preparing for the Olympic Games in 2008, there was a significant reduction of $\mathrm{SO}_{2}$ emissions in north China during the summer of 2008. The error bars in Fig. 7 show the standard deviations of those model runs with the same emissions (see Table 1). For example, for April 2001 (green square in Fig. 7), the error bar represents the standard deviation of all the model results with the TRACE-P inventory for April over the period 2001-2005. The relatively large error bars imply the potentially strong influence of annual meteorological variation on the surface sulfur concentrations, and this will be discussed further in Sect. 4.3.

\subsection{Correlations between $\mathrm{SO}_{2}$ emission and the acid rain situation in China}

Acid rain is a serious and growing problem in China (Larssen et al., 2006; Nagase and Silva, 2007; Zhao et al., 2009). Although $\mathrm{NO}_{\mathrm{x}}, \mathrm{PM}, \mathrm{NH}_{3}$, and other species also contribute to the acidification, $\mathrm{SO}_{2}$ emission is still believed to be the major cause of the acid rain in China (Larssen et al., 2006). The increase of $\mathrm{SO}_{2}$ emission between 2000 and 2006 ought to have worsened the acid rain situation. Figure 8 shows the acid rain frequencies and precipitation $\mathrm{pH}$ in cities under the National Acid Rain Monitoring Program of China during 2000-2008. The proportion of cities experiencing acid rain with a frequency of $>50 \%$ and $>75 \%$ increased between 2000 and 2005; meanwhile the proportion of cities experiencing moderate and heavy acid rain (average $\mathrm{pH}$ of precipitation less than 5.0 and 4.5 , respectively) increased too, indicating the acid rain problem was getting more severe year by year. After 2005, the acid rain problem in Chinese cities was alleviated in both frequency and average precipitation $\mathrm{pH}$ value. All these findings are consistent with the $\mathrm{SO}_{2}$ emission trend and $\mathrm{SO}_{2}$ concentration trend in China after 2000, as shown in the previous sections. In addition, the emissions of other acidifying species seem to follow the same trends as $\mathrm{SO}_{2}$ before 2005 (Zhao et al., 2009). For example, $\mathrm{NO}_{\mathrm{x}}$ emission in China was estimated to increase by 57\% between 2000 and 2005 (Zhang et al., 2007, 2009a), which was driven by the dramatic increase of fuel consumption in power plants (same as $\mathrm{SO}_{2}$ ) and vehicle population.

\subsection{Correlations between $\mathrm{SO}_{2}$ emission and $\mathrm{SO}_{2}$ and $\mathrm{SO}_{4}^{2-}$ concentration in Japan and Korea}

Figure 9 shows the percentage change of annual $\mathrm{SO}_{2}$ concentration at about 1000 sites in the Japan National Air Monitoring Network (from the database of Japan NIES) between 2000 and 2007. Unlike China, $\mathrm{SO}_{2}$ concentrations in most cities of Japan tend to continuously decrease after 2000 (Fig. 10a). This is in line with the decrease of both volcanic and local anthropogenic $\mathrm{SO}_{2}$ emission in Japan during the period (Fig. 4). However, some sites close to the Asian continent (e.g., sites in the southwest of Japan) showed an opposite increasing trend. The inset of Fig. 9 plots the percentage change of $\mathrm{SO}_{2}$ in each site versus each site's longitude. Although the data are scattered, the $\mathrm{SO}_{2}$ percentage change is generally decreasing with longitude, indicating that the further the site is from the Asian continent, the greater the $\mathrm{SO}_{2}$ concentration decrease. Recently, Aikawa et al. (2010) found a significant longitudinal/latitudinal gradient in the measured and modeled $\mathrm{SO}_{4}^{2-}$ concentrations over the East Asian Pacific Rim region, and the $\mathrm{SO}_{4}^{2-}$ concentrations 

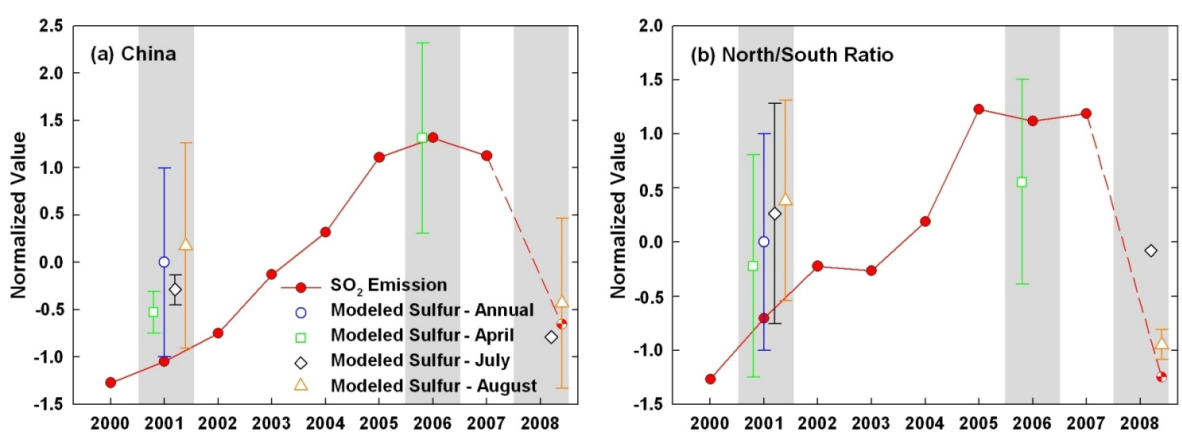

Fig. 7. (a) Inter-annual trends of normalized $\mathrm{SO}_{2}$ emissions and simulated total surface sulfur $\left(\mathrm{SO}_{2}+\mathrm{SO}_{4}^{2-}\right)$ concentrations averaged over China. (b) Inter-annual trends of the normalized ratio of $\mathrm{SO}_{2}$ emissions and the simulated total surface sulfur concentrations between north and south China. The emission of 2008 shown is targeting the Olympic-Base inventory (consistent with the STEM model run in 2008). The markers at years 2001, 2006, and 2008 (as indicated in the gray areas) represent the simulation results of model runs with emissions targeting the corresponding years. The respective error bars show the standard deviation of all available model runs with the same emissions (see Table 1 for details).
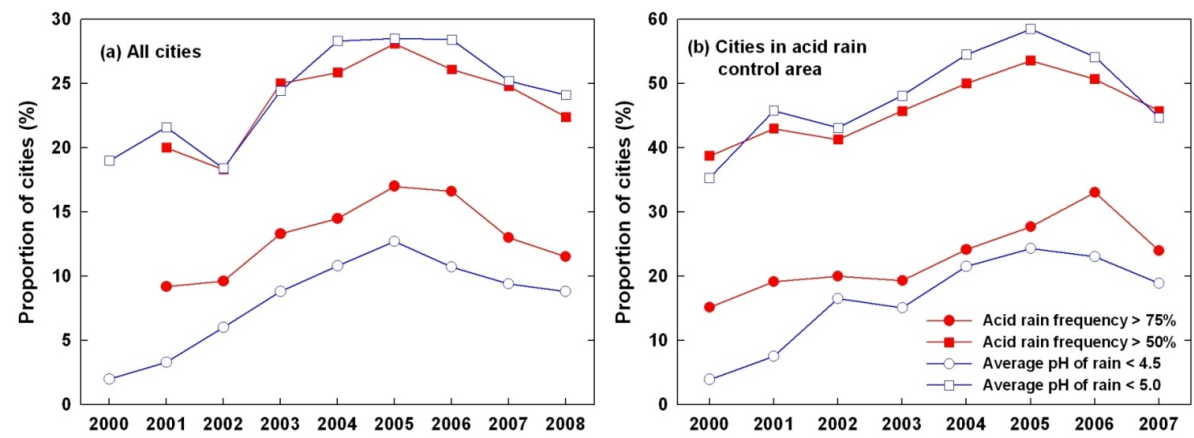

Fig. 8. Proportion of cities with acid rain frequencies above $50 \%$ and $75 \%$, and with average pH values of precipitation below 5.0 and 4.5 in China. (a) All cities under the National Acid Rain Monitoring Program. (b) Cities in the acid rain control area.

were higher at the sites closer to the Asian continent. On the other hand, they found no such distinct gradient in $\mathrm{SO}_{2}$ concentrations. However, in this study, we found a longitudinal gradient in the percentage change of urban $\mathrm{SO}_{2}$ concentration in Japan during 2000-2007. It is reasonable to believe that the longer lifetime of $\mathrm{SO}_{4}^{2-}$ enables it to be transported over longer distances, whereas the shorter lifetime of $\mathrm{SO}_{2}$ makes it more correlated with local emissions. However, our result clearly demonstrates that, in spite of the relatively short tropospheric lifetime of $\mathrm{SO}_{2}$, the transport of increasing $\mathrm{SO}_{2}$ from the Asian continent partially counteracts the local reduction of $\mathrm{SO}_{2}$ emission downwind, and even overrides it in some southwest areas of Japan.

As mentioned above, the spatial distribution of $\mathrm{SO}_{2}$ and $\mathrm{SO}_{4}^{2-}$ concentration over the East Asian Pacific Rim region was analyzed in a recent study (Aikawa et al., 2010). Different from their work, here we focus on the inter-annual variations of $\mathrm{SO}_{2}$ and $\mathrm{SO}_{4}^{2-}$ concentration. Figure 11 shows the inter-annual variations of $\mathrm{SO}_{2}$ concentration at EANET sites. As illustrated, there are 10 sites in Japan and 3 sites in South Korea. A little different from the data of Japan NIES, $\mathrm{SO}_{2}$ concentrations at most of the EANET sites show an increasing trend, except Ijira and Banryu in Japan and Kanghwa and Imsil in South Korea (Fig. 11). It should be noticed that these four sites are either urban or rural sites, whereas all the other sites are remote sites. Figure 10a displays the inter-annual variation of $\mathrm{SO}_{2}$ average concentration over remote and other (urban and rural) EANET sites separately. Apparently, $\mathrm{SO}_{2}$ concentrations at urban and rural EANET sites decreased after 2000, and this is in line with the trend in Japan NIES sites, which are mostly located in urban areas as well. The substantial increase in $\mathrm{SO}_{2}$ concentration at remote sites during 2002-2007 is probably attributed to the $\mathrm{SO}_{2}$ emission increase on the Asian continent. The background $\mathrm{SO}_{2}$ increase can also be observed in the $\mathrm{SO}_{2}$ retrievals of SCIAMACHY and OMI in Fig. 6.

As distinct from primary emitted gaseous $\mathrm{SO}_{2}, \mathrm{SO}_{4}^{2-}$ in aerosols are mostly secondary air pollutants and are formed in the atmosphere through either gas-phase oxidation of $\mathrm{SO}_{2}$ with $\mathrm{OH}$, or conversion of $\mathrm{SO}_{2}$ in cloud by $\mathrm{H}_{2} \mathrm{O}_{2}$ and $\mathrm{O}_{3}$. Since the dry deposition velocity of sulfate aerosol is much less than that of $\mathrm{SO}_{2}$, sulfate aerosols may be transported 


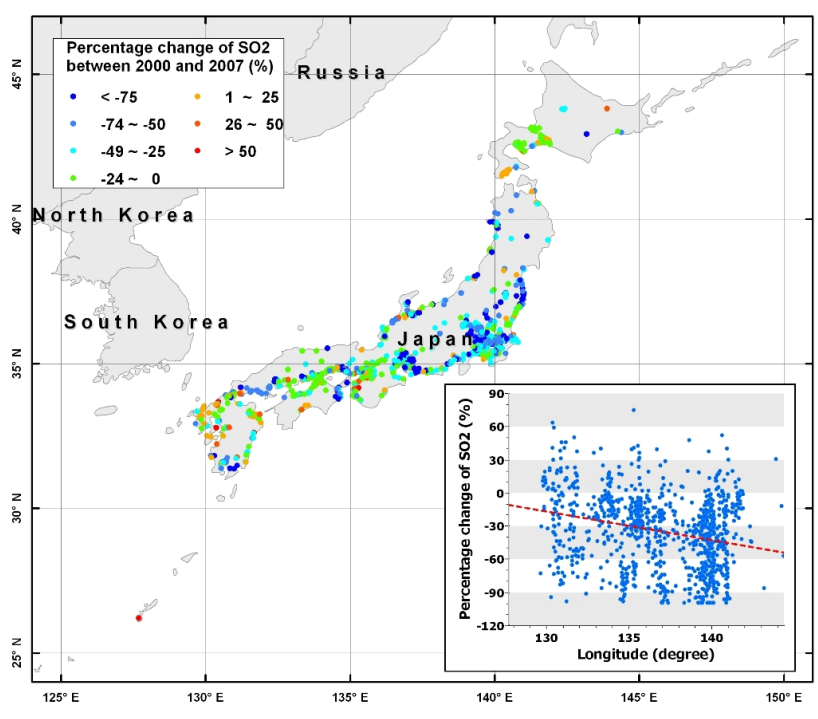

Fig. 9. Percentage change of annual $\mathrm{SO}_{2}$ concentration at sites of the Japan National Air Monitoring Network between 2000 and 2007 (from database of Japan NIES). The inset plots the percentage change of $\mathrm{SO}_{2}$ versus site longitude.

for longer distances than $\mathrm{SO}_{2}$. The transport of $\mathrm{SO}_{4}^{2-}$ from the Asian continent to South Korea and Japan has been reported using both back-trajectory analysis (Kitayama et al., 2010; Osada et al., 2003) and the Community Multiscale Air Quality (CMAQ) modeling (Aikawa et al., 2010; Lin et al., 2008). The inter-annual variations of measured $\mathrm{SO}_{4}^{2-}$ at EANET sites are shown in Fig. 12 and Fig. 10b. Except for Kanghwa in South Korea, the sulfate concentrations in PM of all the EANET sites have increasing tendencies after 2003, which is consistent with the $\mathrm{SO}_{2}$ emission increase in China during this period. In addition, the increasing trend for most sites levels off and changes to a decreasing trend around 2005 to 2006, which is also in agreement with the $\mathrm{SO}_{2}$ emission change in China after 2005 (Fig. 2). The concurrent decrease in both $\mathrm{SO}_{2}$ and $\mathrm{SO}_{4}^{2-}$ concentration $(>60 \%$ decrease in $\mathrm{SO}_{4}^{2-}$ and $>30 \%$ decrease in $\mathrm{SO}_{2}$ ) at the Kanghwa site may be due to a large reduction in local $\mathrm{SO}_{2}$ emission.

To summarize, the increasing trends of both background $\mathrm{SO}_{2}$ and $\mathrm{SO}_{4}^{2-}$ concentrations after 2000 are in line with the $\mathrm{SO}_{2}$ emission changes in China. Based on the EANET data, the average concentrations of $\mathrm{SO}_{2}$ and $\mathrm{SO}_{4}^{2-}$ at all sites increased by $15.0 \%$ and $24.1 \%$ from 2003 to 2007 , respectively, whereas the $\mathrm{SO}_{2}$ emission in China increased by $21.0 \%$ over the same four-year period. Therefore, between 2003 and 2007, a 1\% $\mathrm{SO}_{2}$ emission increase in China corresponds to approximately $0.71 \%$ and $1.15 \%$ increase in $\mathrm{SO}_{2}$ and $\mathrm{SO}_{4}^{2-}$ concentrations in Japan and South Korea, respectively. These two values are in good agreement with the model results of Manktelow et al. (2007), in which, between 1985 and 2000, every 1\% $\mathrm{SO}_{2}$ emission increase in East Asia resulted in $0.74 \%$ increase in surface $\mathrm{SO}_{2}$ concentration and
$1.29 \%$ increase in surface aerosol sulfate concentration. The fact that the $\mathrm{SO}_{4}^{2-}$ concentration increased at a greater rate than the emission, whereas the $\mathrm{SO}_{2}$ concentration increased at a lower rate, indicates that East Asia is a less oxidantlimited area than other areas in the world (Manktelow et al., 2007). The high concentrations of $\mathrm{OH}, \mathrm{H}_{2} \mathrm{O}_{2}$ and $\mathrm{O}_{3}$ in the atmosphere enhance both the dry and in-cloud oxidation of $\mathrm{SO}_{2}$, and thus increase the conversion efficiency of $\mathrm{SO}_{2}$ to sulfate.

As mentioned in Sect. 4.1, the influence of annual meteorological variation on the surface sulfur concentrations is probably strong in East Asia during 2000-2008. Using the STEM model results, we find that the inter-annual variation of meteorology also contributes to the observed trends at some individual sites. Figure 13 gives the normalized interannual trends of modeled and observed $\mathrm{SO}_{2}$ concentrations from 2001 to 2008 at two selected EANET sites, Kanghwa in South Korea (urban/rural site) and Yusuhara in Japan (remote site). The STEM model results for 2001 to 2005 were obtained with constant emissions (TRACE-P) but varying meteorology, whereas the results from 2001 to 2008 include the effects of both changes in emissions and meteorology. In general, the modeled $\mathrm{SO}_{2}$ concentrations in April, July, and August are consistent with the observations. The error bars in Fig. 13 show the ranges of those model results with constant emissions (see Table 1), which allow us to explore the importance of inter-annual variability in meteorology. The size of these bars and the high correlation between the observed and modeled $\mathrm{SO}_{2}$ concentrations from 2001 to 2005 indicate that meteorology itself can play a very important role in terms of the observed variations in $\mathrm{SO}_{2}$ concentrations. Therefore, it is not appropriate to infer the correlation between $\mathrm{SO}_{2}$ emissions and sulfur observations from individual sites, but only from the average over a large number of sites. For example, due to the meteorological variation, the data points in the inset of Fig. 9 are highly scattered, and results for a single site may not be significant. However, a longitudinal gradient can be found over all 1000 sites, clearly indicating the effect of $\mathrm{SO}_{2}$ emission from the Asian continent.

\section{Contribution of sulfate to aerosols over East Asia}

\subsection{Correlations between $\mathrm{SO}_{2}$ emission and SSR}

Recently, we reported a comparison of estimated AOD and SSR observations in eight world regions from 1980 to 2006 (Streets et al., 2009). The SSR observations used in that work are a subset of the data reported by Wild et al. (2009) (hereafter Wild-SSR). The directions of the estimated and observed trends for most of the defined regions were the same, except for East Asia. Especially in the period between 2000 and 2005, the trends of normalized SSR and normalized $\exp (-\mathrm{AOD})$ were apparently different (Fig. 6 in Streets et al., 2009). Since the estimated AOD was based on the 

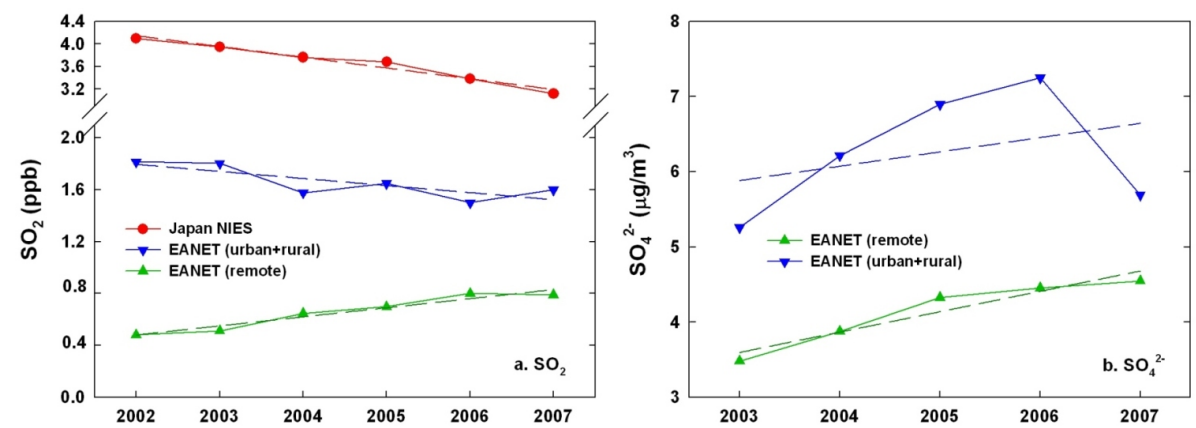

Fig. 10. Inter-annual variation of $\mathrm{SO}_{4}^{2-}$ and $\mathrm{SO}_{2}$ average concentrations at Japan NIES sites and EANET sites. Dashed lines represent the linear tendencies.

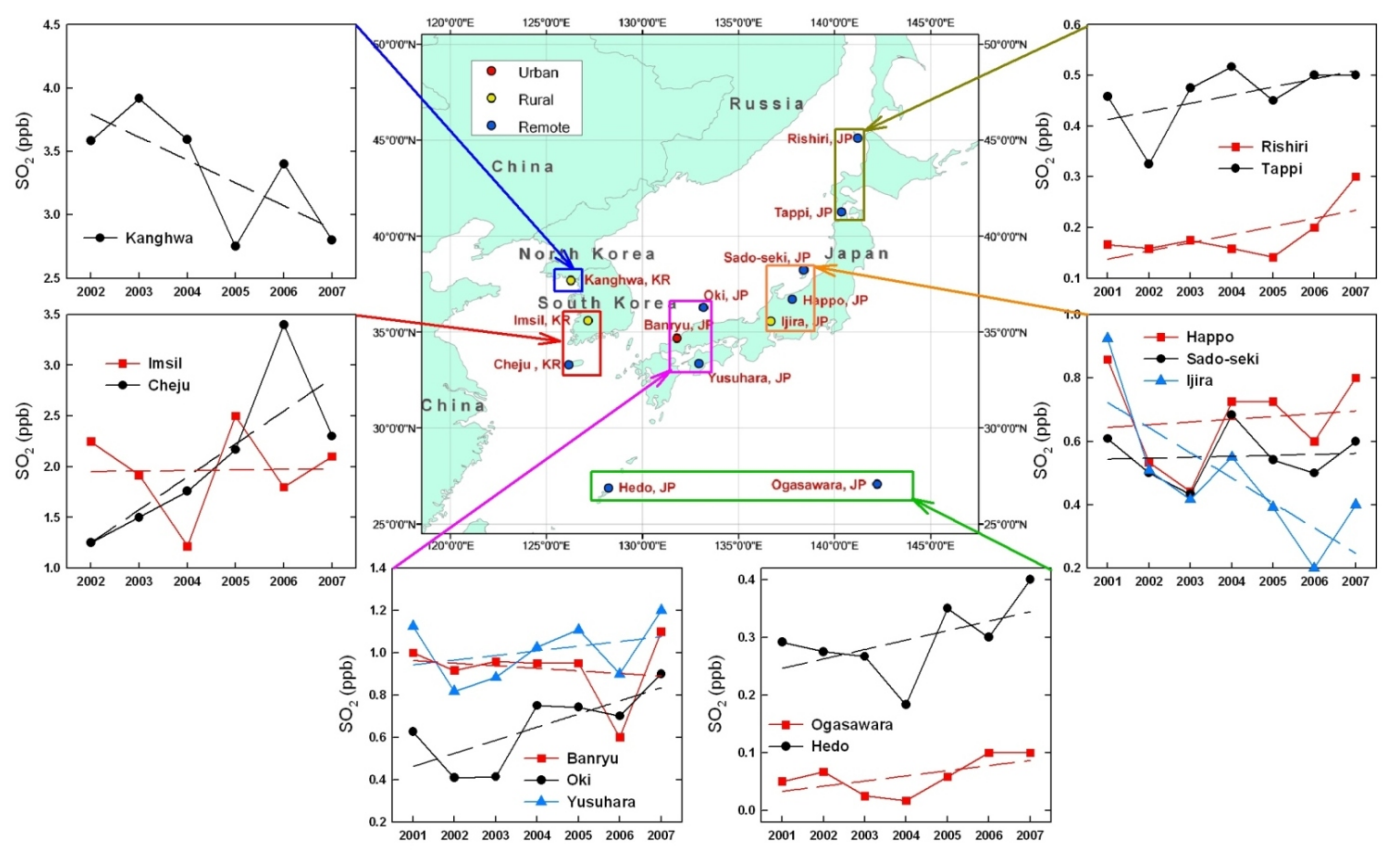

Fig. 11. Inter-annual trends of $\mathrm{SO}_{2}$ at 13 EANET sites from 2001 to 2007. Dashed lines represent the linear tendencies.

result of a single-year (2001), full model run of the GOCART model, and was determined from the linear relationship established between AOD and emission, the trend of estimated AOD represented the trend of emissions of primary aerosol and precursor species (i.e., $\mathrm{BC}, \mathrm{OC}$, dust, $\mathrm{SO}_{2}$, and $\mathrm{DMS}$ ). The contributions to AOD from natural sources of aerosols revealed no long-term changes (Fig. 4 in Streets et al., 2009), and sulfate (of which the precursor is $\mathrm{SO}_{2}$ ) accounted for more than $80 \%$ of the anthropogenic contribution. Thus, to a large extent, the trend in estimated AOD over East Asia ought to mirror the trend in $\mathrm{SO}_{2}$ emission. The apparent discrepancy between the estimated AOD trend and the Wild-SSR observations was puzzling, because a previous comparison that had used a Chinese data set of SSR observations (Streets et al., 2008) had shown good agreement. In the following paragraphs, we reanalyze the Wild-SSR data used in Streets et al. (2009), to try to explain the apparent discrepancy between the observed SSR and the estimated $\exp (-\mathrm{AOD})$ and to better understand the contribution of East Asian sulfate to reduced solar radiation reaching Earth's surface.

In the work of Streets et al. (2009), SSR data from fourteen Japan sites, seven China sites, three Mongolia sites, and four Korea sites were used to represent the surface solar radiation of the whole of East Asia region. These data were selected from the Wild-SSR data set because of their long period of reliable records (Wild et al., 2009). The estimated AOD data were based on total East Asia emission, and thus expressed the overall optical properties of aerosols in the entire East Asia atmosphere. Therefore, there is a question about whether the data for the 28 selected sites is truly representative of the average SSR over the whole region. Figure 14 compares the annual time series of normalized mean SSR 


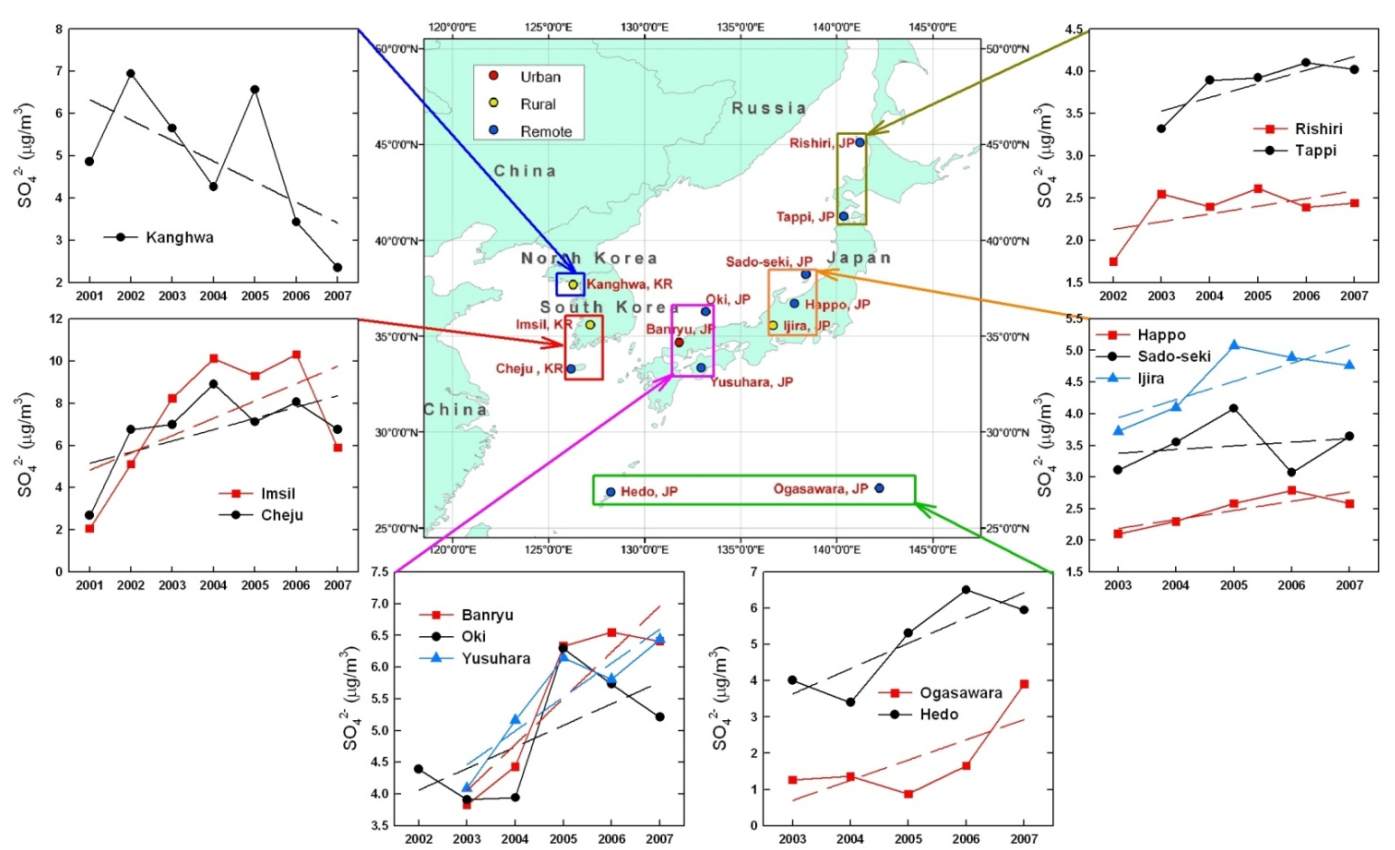

Fig. 12. Inter-annual trends of $\mathrm{SO}_{4}^{2-}$ in $\mathrm{PM}$ at 13 EANET sites from 2001 to 2007. Dashed lines represent the linear tendencies.
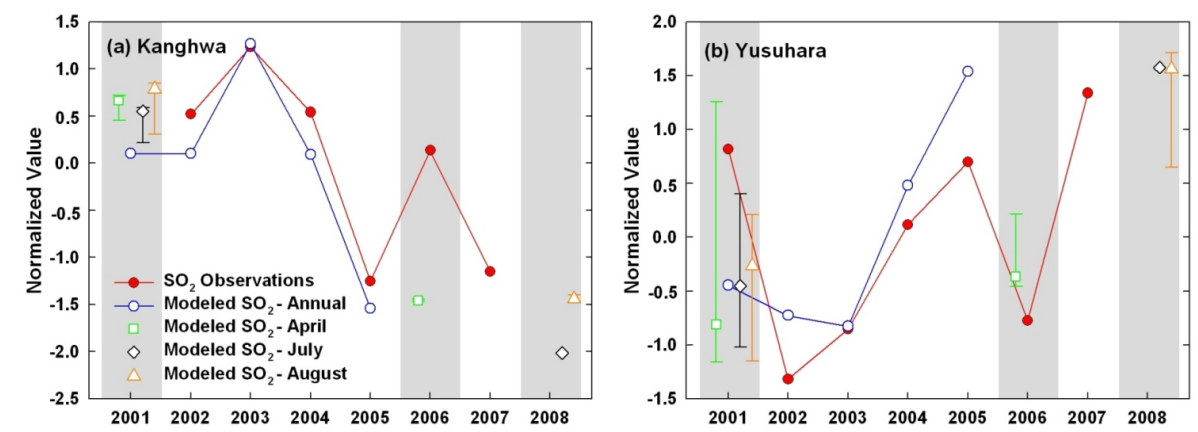

Fig. 13. Normalized inter-annual trends of modeled and observed $\mathrm{SO}_{2}$ concentrations from 2001 to 2008 at (a) Kanghwa site in South Korea and (b) Yusuhara site in Japan. The annual model results are obtained from the runs with constant emission (TRACE-P). The markers at years 2001, 2006, and 2008 (as indicated in the gray areas) represent the simulation results of model runs with emissions targeting the corresponding years. The respective error bars show the ranges of all available model results with the same emissions (see Table 1 for details).

observations and MODIS exp(-AOD) mean values for the 28 sites, by region, in which the AOD data are extracted from the grid boxes of the MODIS monthly level-3 dataset where SSR sites are located. We divide the 28 SSR sites into three regions (Japan, China/Mongolia, and South Korea), and the annual time series for each region is determined by averaging over the complete records of the individual sites. As shown in Fig. 14, the SSR observations and the MODIS exp(-AOD) at the 28 sites have nearly the same inter-annual variations ( $R=0.96$ for all sites, Fig. 14d). Even in 2003, MODIS AOD data can mirror the low insolation in East Asia, which may be correlated with the anomalously high insolation in Europe and be a consequence of the quasi-stationary behav- ior of the planetary wave in the unusual summer of 2003 (Wild et al., 2009). This result suggests that the MODIS AOD data are consistent with solar radiation measurements in East Asia.

Figure 15 displays four separate annual time series of AOD trends averaged over the region of Japan, East Asia, Japan-excluded East Asia, and the grid boxes where 28 SSR sites are located, for both the MODIS and MISR satellite retrievals from 2000 to 2008 . The correlation coefficients $(R)$ between the datasets are shown in Table 4 . The AOD variations at the 28 SSR sites are highly correlated with AOD averaged over Japan ( $R=0.90$ for MODIS and $R=0.89$ for MISR), whereas both of them are relatively poorly correlated 

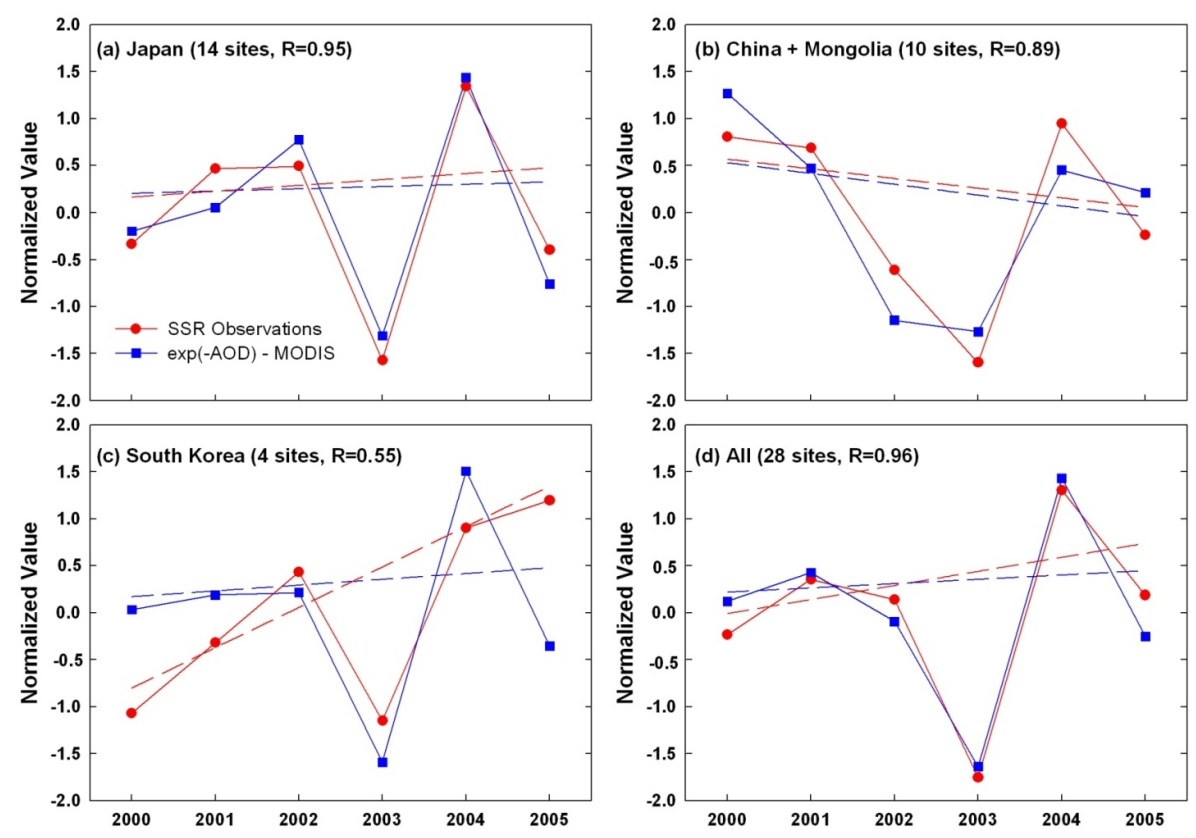

Fig. 14. Evolutions of normalized annual mean SSR observations and exp(-AOD) from MODIS at SSR observation sites in (a) Japan, (b) China and Mongolia, (c) South Korea, and (d) East Asia (all 28 sites). Dashed lines represent the linear tendencies excluding the year 2003 data.

Table 4. Correlation coefficients $(R)$ between the data sets in Fig. 15.

\begin{tabular}{lrrrr}
\hline MODIS (MISR & 28 SSR Sites & Japan & East Asia & $\begin{array}{r}\text { East Asia } \\
- \text { Japan }^{\mathrm{b}}\end{array}$ \\
\hline 28 SSR Sites & 1 & & & \\
Japan & $0.90(0.89)$ & 1 & & \\
East Asia & $0.74(0.73)$ & $0.58(0.64)$ & 1 & \\
East Asia - Japan & $0.66(0.69)$ & $0.47(0.58)$ & $0.99(1.00)$ & 1 \\
\hline
\end{tabular}

a Values in parenthesis are the $R$ values between MISR AOD data sets;

${ }^{\mathrm{b}}$ East Asia excluding Japan.

with the AOD variation averaged over East Asia and Japanexcluded East Asia $(R=0.47-0.74)$. Therefore, due to the large number of Japanese monitoring sites in the SSR observational dataset, the 28 SSR sites are predominantly representative of Japan rather than the whole of East Asia, while the average AOD of the whole of East Asia is representative of the emission of the Japan-excluded East Asia region (mostly China). This may explain the discrepancy between the observed Wild-SSR and the estimated $\exp (-\mathrm{AOD})$ in East Asia during 2000-2005 reported by Streets et al. (2009).

Returning to the issue of dimming and brightening in East Asia, as the linear tendencies of each dataset show in Fig. 14 and Fig. 15, Japan and South Korea showed a brightening between 2000 and 2005 (Fig. 14a, c). However, the brightening in Japan leveled off and perhaps reverted to a dimming after 2005 (Fig. 15). On the other hand, China and the whole of East Asia underwent a continuous dimming in solar radiation after 2000 (Fig. 14b and Fig. 15). These are consistent with the conclusions of Wild et al. (2009) and Norris and Wild (2009). The continuous dimming in China and East Asia is consistent with the dramatic increase in $\mathrm{SO}_{2}$ emission in East Asia after 2000 and provides further evidence to confirm our hypothesis that changes in AOD over time, particularly the regional transitions from dimming to brightening, are caused by the changing patterns of anthropogenic emissions of aerosols and aerosol precursors (Streets et al., 2006a, 2008, 2009).

\subsection{Correlations between $\mathrm{SO}_{2}$ emission and AOD}

Figure 16 shows comparisons of three-year central moving average values of normalized $\mathrm{SO}_{2}$ emission in China with AOD values averaged over East Asia from MODIS and MISR satellite retrievals, as well as with AOD simulated by the GOCART model. As shown in Fig. 16a, although the datasets have obviously different inter-annual variations, the tendencies are the same, showing an increase in AOD over East Asia after 2000. This is consistent with the work of van Donkelaar et al. (2008). They analyzed the MODIS and MISR AOD for 2000-2006 over eastern China, and found increases of 4.1\%/year and 3.4\%/year in MODIS and MISR AOD, respectively. It should be noted that this conclusion was drawn when they focused their analysis between July and December of each year. During this period, their GEOS- 

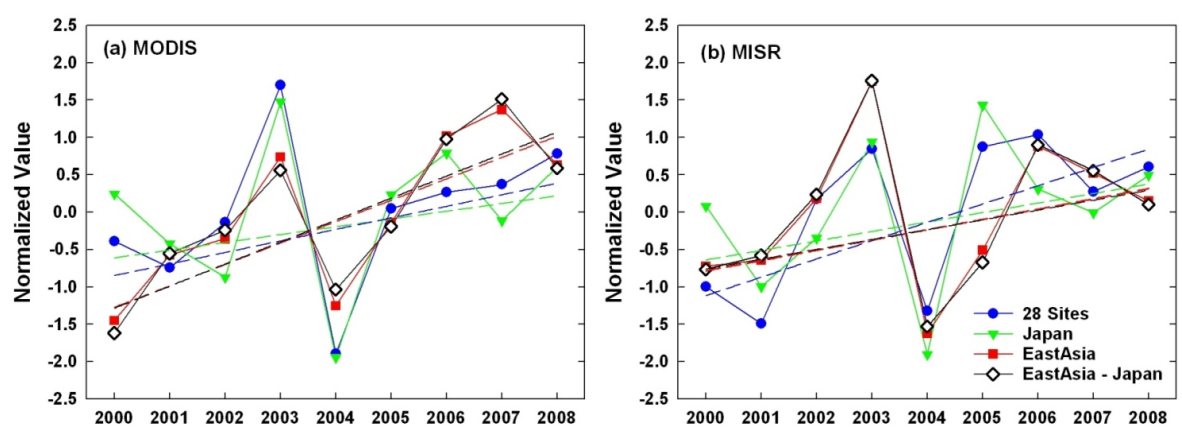

Fig. 15. Evolutions of MODIS AOD and MISR AOD averaged over 28 SSR sites, Japan, East Asia, and Japan-excluded East Asia. Dashed lines represent the linear tendencies excluding the year 2003 data.
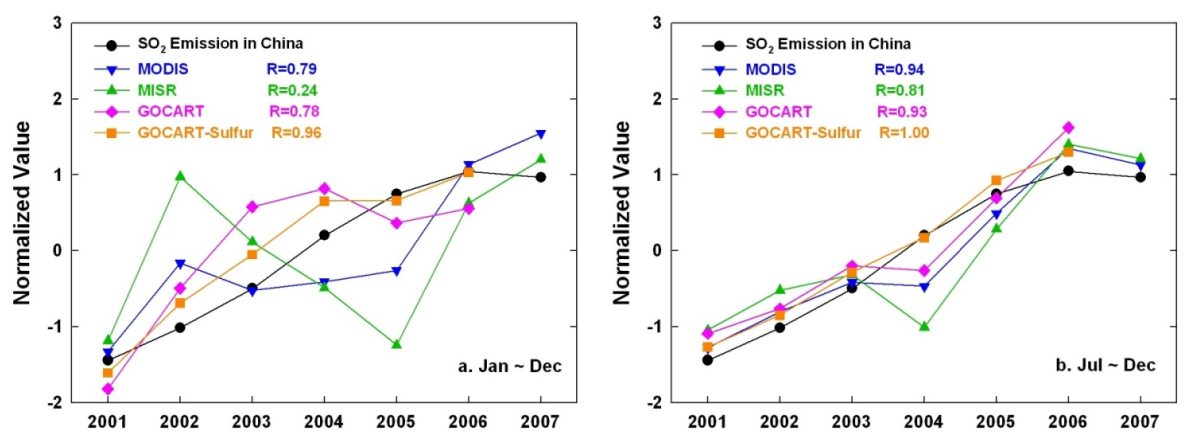

Fig. 16. Three-year central moving average values of normalized China $\mathrm{SO}_{2}$ emission, MODIS AOD, MISR AOD, GOCART AOD, and the sulfur portion of GOCART AOD over East Asia. Values are averaged (a) from January to December and (b) from July to December of each year. $R$ values shown are the correlation coefficients of each dataset with $\mathrm{SO}_{2}$ emission in China.

Chem model results showed sulfur contributed to $56 \%$ of total AOD in China. We present the monthly AOD variations of the major aerosol components over the whole of East Asia region from GOCART model results in Fig. 17. As van Donkelaar et al. (2008) found in their GEOS-Chem results, the GOCART simulation indicates that dust comprises the largest fraction of AOD in spring and the contribution of sulfur to total AOD peaks in the second half of the year. Therefore, we further compare the AOD trend of MODIS, MISR, GOCART, and $\mathrm{SO}_{2}$ emission semiannually (from July to December, Fig. 16b). The seasonal variation of $\mathrm{SO}_{2}$ emission in China is not taken into account in Fig. 16b because China's $\mathrm{SO}_{2}$ emission mainly comes from power and industrial emissions and has a weak seasonal change (Zhang et al., 2009a). Clearly, AOD trends agree much better with $\mathrm{SO}_{2}$ emission in China during the period of July to December. $R$ values between $\mathrm{SO}_{2}$ emission and each AOD dataset increase significantly from $0.24-0.96$ to $0.81-1.00$, indicating that the effect of emission in China on AOD is more pronounced during the second half of the year. Additionally, the decline of both MODIS and MISR AOD (Fig. 15, Fig. 16b) in East Asia after 2006 corresponds well with the decrease of China $\mathrm{SO}_{2}$ emission, further indicating the close relationship between $\mathrm{SO}_{2}$ emission and AOD.

\section{Summary and conclusions}

The $\mathrm{SO}_{2}$ emission in China increased dramatically since 2000 due to the rapid increase of fossil-fuel consumption, consistent with rapid economic development. Using a detailed technology-based methodology specifically for China, we estimate that $\mathrm{SO}_{2}$ emission in China increased by $53 \%$, from $21.7 \mathrm{Tg}$ in 2000 to $33.2 \mathrm{Tg}$ in 2006 , at an annual growth rate of $7.3 \%$. Power plants are the main source of $\mathrm{SO}_{2}$ in China, contributing more than $50 \%$ to the total emission, and it was growth in the power sector that was largely responsible for the big increase in emissions. The growth of China's $\mathrm{SO}_{2}$ emission began to slow down around 2005, and emission then began to decrease after 2006, mainly due to the application of FGD devices in power plants. The changes in emission since 2000 are not uniform geographically. From 2000 to 2006, $\mathrm{SO}_{2}$ emission from north China increased by $85 \%$, whereas that from south China increased by only $28 \%$.

Potentially, these changes in $\mathrm{SO}_{2}$ emissions should be reflected in trends in other sulfur-related quantities in China and throughout the East Asia region. To examine this question, we compared the $\mathrm{SO}_{2}$ emission with a variety of official environmental statistics, ground-based measurements, satellite observations, and model results. The following findings and conclusions can be drawn: 


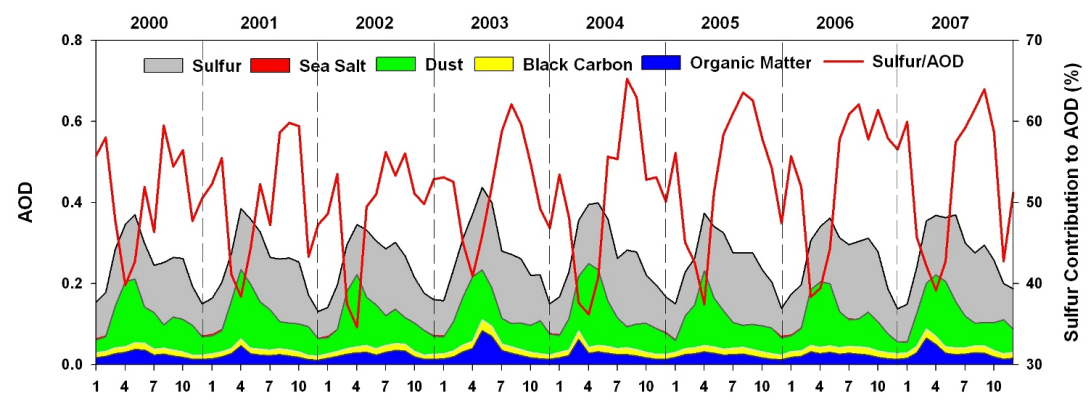

Fig. 17. Monthly variation of GOCART AOD and the contribution of sulfur to total AOD over East Asia during $2000-2007$.

1. The change of $\mathrm{SO}_{2}$ emission in China after 2000 is generally in line with the change of $\mathrm{SO}_{2}$ concentration (from both ground-based measurements and satellite observations) in China, confirming the fact that $\mathrm{SO}_{2}$ is a primary air pollutant with a relatively short lifetime, and its concentration reflects the emission level of its surrounding area. In addition, the trend of $\mathrm{SO}_{2}$ emission is in good agreement with the trends of acid rain $\mathrm{pH}$ and frequency in China.

2. The $\mathrm{SO}_{2}$ concentrations in most cities of Japan tend to continuously decrease after 2000, which is attributed to the decreasing trend of both local anthropogenic and volcanic emissions. A longitudinal gradient in the percentage change of urban $\mathrm{SO}_{2}$ concentration in Japan is found during 2000-2007, which implies that the further the site is from the Asian continent, the higher degree of the $\mathrm{SO}_{2}$ concentration decrease there is. This result demonstrates that, in spite of the relatively short tropospheric lifetime of $\mathrm{SO}_{2}$, the transport of increasing $\mathrm{SO}_{2}$ from the Asian continent can partially counteract the local reduction of $\mathrm{SO}_{2}$ emission downwind, and even overrides it in some southwestern areas of Japan.

3. The background $\mathrm{SO}_{2}$ and $\mathrm{SO}_{4}^{2-}$ concentrations in East Asia show increasing trends, which are consistent with the $\mathrm{SO}_{2}$ emission increase on the Asian continent. The fact that the $\mathrm{SO}_{4}^{2-}$ concentration increases at a greater rate than the emission, while the $\mathrm{SO}_{2}$ concentration increases at a lower rate, suggests that East Asia is a less oxidant-limited area than other parts of the world.

4. We reanalyze the SSR data used in Streets et al. (2009) and find that the limited Wild-SSR data in East Asia is not truly representative of the average SSR over East Asia. This caused the discrepancy between the estimated AOD trend and the Wild-SSR observations in the work of Streets et al. (2009). The MODIS AOD data are highly correlated with the solar radiation measurements in East Asia. Using MODIS AOD data as a surrogate of SSR, we found China and East Asia excluding Japan underwent a continuous dimming after 2000 , which is consistent with the dramatic increase in $\mathrm{SO}_{2}$ emission in East Asia.

5. The AOD values averaged over East Asia from MODIS and MISR satellite retrievals and GOCART model results increased after 2000, again in line with the $\mathrm{SO}_{2}$ emission change in China. The correlations are more pronounced when the second half-year AOD data are compared, since sulfur contributes the largest fraction of AOD in that period.

We have demonstrated that $\mathrm{SO}_{2}$ emissions in China increased by $53 \%$ between 2000 and 2006 . This means that the amount of sulfur injected into the East Asian atmosphere was much greater than it had been previously. Undoubtedly, this led to increased ambient concentrations, deposition, and transport of sulfur species in both gaseous and aerosol form. We can presume that deleterious human health effects and ecosystem damage resulted. The positive side of the situation is that $\mathrm{SO}_{2}$ emission in China after 2005 stabilized and began to decrease, which is reflected in the decreasing trends of $\mathrm{SO}_{2}$ and $\mathrm{SO}_{4}^{2-}$ concentrations, acid rain $\mathrm{pH}$ and frequency, $\mathrm{AOD}$, etc., in East Asia after 2006-2007. The decline of $\mathrm{SO}_{2}$ emission is mainly caused by the widespread installation of FGD devices in power plants, which is enforced by the Chinese government during the 11th Five-Year Plan period (20062010). A recent statistical report from the China MEP shows that the FGD penetration of power plants had reached $71 \%$ by the end of 2009 and is expected to rise to $73 \%$ at the end of 2010 (Ministry of Environmental Protection, 2010). This implies that the $\mathrm{SO}_{2}$ emissions from the power sector (which is the biggest contributor to national emissions) in China will continue to decrease after 2008. Correspondingly, therefore, there would have been significant benefits to human health and the ecosystem that can be attributed to the $\mathrm{SO}_{2}$ control measures adopted by China's MEP in 2005. It should be noted, however, that $\mathrm{SO}_{2}$ emission from industrial coal combustion has increased substantially in recent years, due to increasing coal consumption and the low application rate of $\mathrm{SO}_{2}$ control techniques in the industry sector. Hence, emission control in industry is highly recommended to policy makers for the next step in $\mathrm{SO}_{2}$ control in China. 
Acknowledgements. This work was funded by NASA's ARCTAS mission under proposal No. 07-ARCTAS07-0023. The authors are grateful to Jay Al-Saadi, Jim Crawford, and Hal Maring of NASA for their support. Argonne National Laboratory is operated by University of Chicago Argonne, LLC, under Contract No. DE-AC02-06CH11357 with the US Department of Energy.

Edited by: C. H. Song

\section{References}

Adhikary, B., Carmichael, G. R., Tang, Y., Leung, L. R., Qian, Y., Schauer, J. J., Stone, E. A., Ramanthan, V., and Ramana, M. V.: Characterization of the seasonal cycle of South Asian aerosols: a regional-scale modeling analysis, J. Geophys. Res., 112, D22S22, doi:10.1029/2006JD008143, 2007.

Adhikary, B., Kulkarni, S., Dallura, A., Tang, Y., Chai, T., Leung, L. R., Qian, Y., Chung, C. E., Ramanathan, V., and Carmichael, G. R.: A regional scale chemical transport modeling of Asian aerosols with data assimilation of AOD observations using optimal interpolation technique, Atmos. Environ., 42, 8600-8615, 2008.

Aikawa, M., Ohara, T., Hiraki, T., Oishi, O., Tsuji, A., Yamagami, M., Murano, K., and Mukai, H.: Significant geographic gradients in particulate sulfate over Japan determined from multiple-site measurements and a chemical transport model: Impacts of transboundary pollution from the Asian continent, Atmos. Environ., 44, 381-391, 2010.

Akimoto, H., Ohara, T., Kurokawa, J., and Horii, N.: Verification of energy consumption in China during 1996-2003 by using satellite observational data, Atmos. Environ., 40, 7663-7667, 2006.

An, J. L., Ueda, H., Matsuda, K., Hasome, H., and Iwata, M.: Simulated impacts of $\mathrm{SO}_{2}$ emissions from the Miyake volcano on concentration and deposition of sulfur oxides in September and October of 2000, Atmos. Environ., 37, 3039-3046, 2003.

Andres, R. J. and Kasgnoc, A. D.: A time-averaged inventory of subaerial volcanic sulfur emissions, J. Geophys. Res., 103, 25251-25261, 1998.

Bond, T. C., Streets, D. G., Yarber, K. F., Nelson, S. M., Woo, J. H., and Klimont, Z.: A technology-based global inventory of black and organic carbon emissions from combustion, J. Geophys. Res., 109, D14203, doi:10.1029/2003jd003697, 2004.

Bovensmann, H., Burrows, J. P., Buchwitz, M., Frerick, J., Noel, S., Rozanov, V. V., Chance, K. V., and Goede, A. P. H.: SCIAMACHY: Mission objectives and measurement modes, J. Atmos. Sci., 56, 127-150, 1999.

Carmichael, G. R., Adhikary, B., Kulkarni, S., D’Allura, A., Tang, Y., Streets, D., Zhang, Q., Bond, T. C., Ramanathan, V., Jamroensan, A., and Marrapu, P.: Asian aerosols: current and year 2030 distributions and implications to human health and regional climate change, Environ. Sci. Technol., 43, 5811-5817, 2009.

Carn, S. A., Krueger, A. J., Arellano, S., Krotkov, N. A., and Yang, K.: Daily monitoring of Ecuadorian volcanic degassing from space, J. Volcanol. Geoth. Res., 176, 141-150, 2008.

Chin, M., Rood, R. B., Lin, S. J., Muller, J. F., and Thompson, A. M.: Atmospheric sulfur cycle simulated in the global model GOCART: Model description and global properties, J. Geophys. Res., 105, 24671-24687, 2000.
Chin, M., Chu, A., Levy, R., Remer, L., Kaufman, Y., Holben, B., Eck, T., Ginoux, P., and Gao, Q. X.: Aerosol distribution in the Northern Hemisphere during ACE-Asia: Results from global model, satellite observations, and Sun photometer measurements, J. Geophys. Res., 109, D23s90, doi:10.1029/2004jd004829, 2004.

Chin, M., Diehl, T., Dubovik, O., Eck, T. F., Holben, B. N., Sinyuk, A., and Streets, D. G.: Light absorption by pollution, dust, and biomass burning aerosols: a global model study and evaluation with AERONET measurements, Ann. Geophys., 27, 3439-3464, doi:10.5194/angeo-27-3439-2009, 2009.

China Automotive Research Center: China Automotive Industry Yearbook 2000, 2001, 2002, 2003, 2004, 2005, 2006, 2007 2008, China Statistics Press, Beijing, 2000-2008.

Diehl, T., Chin, M., Krotkov, N., Siebert, L., and Carn, S.: A global inventory of subaerial volcanic $\mathrm{SO}_{2}$ emissions from 1979 to 2007 , in preparation, 2010.

Fu, L., Hao, J., He, D., and He, K.: Assessment of vehicular population in China, J. Air Waste Manage., 51, 658-668, 2001.

Fujita, S.: Atmospheric sulfur budget for the Japan area, in: The proceedings of the annual meeting of Japan Society for Atmospheric Environment, 168-169, 1990.

Fujita, S., Sakurai, T., and Matsuda, K.: Wet and dry deposition of sulfur associated with the eruption of Miyakejima volcano, Japan, J. Geophys. Res., 108, 4444, doi:10.1029/2002jd003064, 2003.

Gilgen, H., Wild, M., and Ohmura, A.: Means and trends of shortwave irradiance at the surface estimated from global energy balance archive data, J. Climate, 11, 2042-2061, 1998.

He, K. B., Huo, H., Zhang, Q., He, D. Q., An, F., Wang, M., and Walsh, M. P.: Oil consumption and $\mathrm{CO}_{2}$ emissions in China's road transport: current status, future trends, and policy implications, Energ. Policy, 33, 1499-1507, 2005.

Huebert, B. J., Bates, T., Russell, P. B., Shi, G. Y., Kim, Y. J., Kawamura, K., Carmichael, G., and Nakajima, T.: An overview of ACE-Asia: Strategies for quantifying the relationships between Asian aerosols and their climatic impacts, J. Geophys. Res., 108, 8633, doi:10.1029/2003jd003550, 2003.

Jacob, D. J., Crawford, J. H., Kleb, M. M., Connors, V. S., Bendura, R. J., Raper, J. L., Sachse, G. W., Gille, J. C., Emmons, L., and Heald, C. L.: Transport and Chemical Evolution over the Pacific (TRACE-P) aircraft mission: Design, execution, and first results, J. Geophys. Res., 108, 9000, doi:10.1029/2002jd003276, 2003.

Jacob, D. J., Crawford, J. H., Maring, H., Clarke, A. D., Dibb, J. E., Emmons, L. K., Ferrare, R. A., Hostetler, C. A., Russell, P. B., Singh, H. B., Thompson, A. M., Shaw, G. E., McCauley, E., Pederson, J. R., and Fisher, J. A.: The Arctic Research of the Composition of the Troposphere from Aircraft and Satellites (ARCTAS) mission: design, execution, and first results, Atmos. Chem. Phys., 10, 5191-5212, doi:10.5194/acp-10-5191-2010, 2010.

Kahn, R. A., Gaitley, B. J., Martonchik, J. V., Diner, D. J., Crean, K. A., and Holben, B.: Multiangle Imaging Spectroradiometer (MISR) global aerosol optical depth validation based on 2 years of coincident Aerosol Robotic Network (AERONET) observations, J. Geophys. Res., 110, D10s04, doi:10.1029/2004jd004706, 2005.

Kajino, M., Ueda, H., Satsumabayashi, H., and An, J. L.: Impacts of the eruption of Miyakejima Volcano on air quality over far east Asia, J. Geophys. Res., 109, D21204, 
doi:10.1029/2004jd004762, 2004.

Kannari, A., Tonooka, Y., Baba, T., and Murano, K.: Development of multiple-species $1 \mathrm{~km} \times 1 \mathrm{~km}$ resolution hourly basis emissions inventory for Japan, Atmos. Environ., 41, 3428-3439, 2007.

Kazahaya, K., Shinohara, H., Uto, K., Odai, M., Nalkahori, Y., Mori, H., Iino, H., Miyashita, M., and Hirabayashi, J.: Gigantic $\mathrm{SO}_{2}$ emission from Miyakejima volcano, Japan, caused by caldera collapse, Geology, 32, 425-428, 2004.

Kitayama, K., Simizu, T., and Hara, H.: Impacts of sulfur dioxide from Miyakejima on precipitation chemistry in Japan, Atmos. Environ., 42, 8923-8933, 2008.

Kitayama, K., Murao, N., and Hara, H.: PMF analysis of impacts of $\mathrm{SO}_{2}$ from Miyakejima and Asian continent on precipitation sulfate in Japan, Atmos. Environ., 44, 95-105, 2010.

Klimont, Z., Cofala, J., Xing, J., Wei, W., Zhang, C., Wang, S., Kejun, J., Bhandari, P., Mathur, R., Purohit, P., Rafaj, P., Chambers, A., and Amann, M.: Projections of $\mathrm{SO}_{2}, \mathrm{NO}_{\mathrm{x}}$ and carbonaceous aerosols emissions in Asia, Tellus B, 61, 602-617, 2009.

Krotkov, N. A., Carn, S. A., Krueger, A. J., Bhartia, P. K., and Yang, $\mathrm{K}$.: Band residual difference algorithm for retrieval of $\mathrm{SO}_{2}$ from the aura Ozone Monitoring Instrument (OMI), IEEE T. Geosci. Remote, 44, 1259-1266, 2006.

Krotkov, N. A., McClure, B., Dickerson, R. R., Carn, S. A., Li, C., Bhartia, P. K., Yang, K., Krueger, A. J., Li, Z. Q., Levelt, P. F., Chen, H. B., Wang, P. C., and Lu, D. R.: Validation of $\mathrm{SO}_{2}$ retrievals from the Ozone Monitoring Instrument over NE China, J. Geophys. Res., 113, D16S40, doi:10.1029/2007jd008818, 2008.

Larssen, T., Lydersen, E., Tang, D. G., He, Y., Gao, J. X., Liu, H. Y., Duan, L., Seip, H. M., Vogt, R. D., Mulder, J., Shao, M., Wang, Y. H., Shang, H., Zhang, X. S., Solberg, S., Aas, W., Okland, T., Eilertsen, O., Angell, V., Liu, Q. R., Zhao, D. W., Xiang, R. J., Xiao, J. S., and Luo, J. H.: Acid rain in China, Environ. Sci. Technol., 40, 418-425, 2006.

Lee, C., Richter, A., Lee, H., Kim, Y. J., Burrows, J. P., Lee, Y. G., and Choi, B. C.: Impact of transport of sulfur dioxide from the Asian continent on the air quality over Korea during May 2005, Atmos. Environ., 42, 1461-1475, 2008.

Levelt, P. F., Van den Oord, G. H. J., Dobber, M. R., Malkki, A., Visser, H., de Vries, J., Stammes, P., Lundell, J. O. V., and Saari, H.: The Ozone Monitoring Instrument, IEEE T. Geosci. Remote, 44, 1093-1101, 2006.

Li, C., Krotkov, N. A., Dickerson, R. R., Li, Z., Yang, K., and Chin, M.: Transport and evolution of a pollution plume from northern China: A satellite-based case study, J. Geophys. Res., 115, D00K03, doi:10.1029/2009JD012245, 2010a.

Li, C., Zhang, Q., Krotkov, N. A., Streets, D. G., He, K., Tsay, S.-C., and Gleason, J. F.: Recent large reduction in sulfur dioxide emissions from Chinese power plants observed by the Ozone Monitoring Instrument, Geophys. Res. Lett., 37, L08807, doi:10.1029/2010GL042594, 2010b.

Lin, M., Oki, T., Bengtsson, M., Kanae, S., Holloway, T., and Streets, D. G.: Long-range transport of acidifying substances in east Asia - Part II - Source-receptor relationships, Atmos. Environ., 42, 5956-5967, 2008.

Manktelow, P. T., Mann, G. W., Carslaw, K. S., Spracklen, D. V., and Chipperfield, M. P.: Regional and global trends in sulfate aerosol since the 1980s, Geophys. Res. Lett., 34, L14803, doi:10.1029/2006g1028668, 2007.
Ministry of Environmental Protection: Report on the state of the environment in China 2008, Beijing, 2009.

Ministry of Environmental Protection: Report on the state of the environment in China 2009, Beijing, 2010.

Ministry of the Environment Government: 2005 Research of air pollutant emissions from stationary sources in Japan, 2006.

Nagase, Y. and Silva, E. C. D.: Acid rain in China and Japan: A game-theoretic analysis, Reg. Sci. Urban Econ., 37, 100-120, 2007.

National Bureau of Statistics: China Energy Statistical Yearbook 2000-2002, 2004, 2005, 2006, 2007, 2008, China Statistics Press, Beijing, 2000-2008a.

National Bureau of Statistics: China Industry Economy Statistical Yearbook 2000, 2001, 2002, 2003, 2004, 2005, 2006, 2007, 2008, China Statistics Press, Beijing, 2000-2008b.

National Institute of Environmental Research: 2006 Greenhouse gas and air pollutants emissions in Korea, 2008.

Network Center for EANET: Data Report on the Acid Deposition in the East Asian Region 2000, 2001, 2002, 2003, 2004, 2005, 2006, 2007, 2001-2008.

Newhall, C. G. and Self, S.: The Volcanic Explosivity Index (VEI) - an estimate of explosive magnitude for historical volcanism, J. Geophys. Res., 87, 1231-1238, 1982.

Norris, J. R. and Wild, M.: Trends in aerosol radiative effects over China and Japan inferred from observed cloud cover, solar "dimming," and solar "brightening", J. Geophys. Res., 114, D00d15, doi:10.1029/2008jd011378, 2009.

Ohara, T., Akimoto, H., Kurokawa, J., Horii, N., Yamaji, K., Yan, X., and Hayasaka, T.: An Asian emission inventory of anthropogenic emission sources for the period 1980-2020, Atmos. Chem. Phys., 7, 4419-4444, doi:10.5194/acp-7-4419-2007, 2007.

Okuda, T., Iwase, T., Ueda, H., Suda, Y., Tanaka, S., Dokiya, Y., Fushimi, K., and Hosoe, M.: The impact of volcanic gases from Miyake island on the chemical constituents in precipitation in the Tokyo metropolitan area, Sci. Total Environ., 341, 185-197, 2005.

Osada, K., Kido, M., Iida, H., Matsunaga, K., Iwasaka, Y., Nagatani, M., and Nakada, H.: Seasonal variation of free tropospheric aerosol particles at Mt. Tateyama, central Japan, J. Geophys. Res., 108, 8667, doi:10.1029/2003jd003544, 2003.

Osada, K., Ohara, T., Uno, I., Kido, M., and Iida, H.: Impact of Chinese anthropogenic emissions on submicrometer aerosol concentration at Mt. Tateyama, Japan, Atmos. Chem. Phys., 9, 91119120, doi:10.5194/acp-9-9111-2009, 2009.

Qian, Y., Kaiser, D. P., Leung, L. R., and Xu, M.: More frequent cloud-free sky and less surface solar radiation in China from 1955 to 2000, Geophys. Res. Lett., 33, L01812, doi:10.1029/2005g1024586, 2006.

Remer, L. A., Kaufman, Y. J., Tanre, D., Mattoo, S., Chu, D. A., Martins, J. V., Li, R. R., Ichoku, C., Levy, R. C., Kleidman, R. G., Eck, T. F., Vermote, E., and Holben, B. N.: The MODIS aerosol algorithm, products, and validation, J. Atmos. Sci., 62, 947-973, 2005.

Schnetzler, C. C., Bluth, G. J. S., Krueger, A. J., and Walter, L. S.: A proposed volcanic sulfur dioxide index (VSI), J. Geophys. Res., 102, 20087-20091, 1997.

Siebert, L. and Simkin, T.: Volcanoes of the world: An illustrated catalog of holocene volcanoes and their eruptions, Smithsonian 
Institution, Global Volcanism Program Digital Information Series, GVP-3, 2002.

Singh, H. B., Brune, W. H., Crawford, J. H., Flocke, F., and Jacob, D. J.: Chemistry and transport of pollution over the Gulf of Mexico and the Pacific: spring 2006 INTEX-B campaign overview and first results, Atmos. Chem. Phys., 9, 2301-2318, doi:10.5194/acp-9-2301-2009, 2009.

Stanhill, G. and Cohen, S.: Global dimming: a review of the evidence for a widespread and significant reduction in global radiation with discussion of its probable causes and possible agricultural consequences, Agr. Forest Meteorol., 107, 255-278, 2001.

State Electricity Regulatory Commission: China Electric Power Yearbook 2001, 2002, 2003, 2004, 2005, 2006, 2007, 2008, China Electric Power Press, Beijing, 2000-2008.

Streets, D. G., Tsai, N. Y., Akimoto, H., and Oka, K.: Sulfur dioxide emissions in Asia in the period 1985-1997, Atmos. Environ., 34, 4413-4424, 2000.

Streets, D. G., Bond, T. C., Carmichael, G. R., Fernandes, S. D., Fu, Q., He, D., Klimont, Z., Nelson, S. M., Tsai, N. Y., Wang, M. Q., Woo, J. H., and Yarber, K. F.: An inventory of gaseous and primary aerosol emissions in Asia in the year 2000, J. Geophys. Res., 108, 8809, doi:10.1029/2002jd003093, 2003.

Streets, D. G., Wu, Y., and Chin, M.: Two-decadal aerosol trends as a likely explanation of the global dimming/brightening transition, Geophys. Res. Lett., 33, L15806, doi:10.1029/2006gl026471, 2006a.

Streets, D. G., Zhang, Q., Wang, L. T., He, K. B., Hao, J. M., Wu, Y., Tang, Y. H., and Carmichael, G. R.: Revisiting China's CO emissions after the Transport and Chemical Evolution over the Pacific (TRACE-P) mission: Synthesis of inventories, atmospheric modeling, and observations, J. Geophys. Res., 111(16), D14306, doi:10.1029/2006jd007118, 2006b.

Streets, D. G., Fu, J. S., Jang, C. J., Hao, J. M., He, K. B., Tang, X. Y., Zhang, Y. H., Wang, Z. F., Li, Z. P., Zhang, Q., Wang, L. T., Wang, B. Y., and Yu, C.: Air quality during the 2008 Beijing Olympic Games, Atmos. Environ., 41, 480-492, 2007.

Streets, D. G., Yu, C., Wu, Y., Chin, M., Zhao, Z., Hayasaka, T., and Shi, G.: Aerosol trends over China, 1980-2000, Atmos. Res., 88, 174-182, 2008.

Streets, D. G., Yan, F., Chin, M., Diehl, T., Mahowald, N., Schultz, M., Wild, M., Wu, Y., and Yu, C.: Anthropogenic and natural contributions to regional trends in aerosol optical depth, 1980-2006, J. Geophys. Res., 114, D00d18, doi:10.1029/2008jd011624, 2009.

van Donkelaar, A., Martin, R. V., Leaitch, W. R., Macdonald, A. M., Walker, T. W., Streets, D. G., Zhang, Q., Dunlea, E. J., Jimenez, J. L., Dibb, J. E., Huey, L. G., Weber, R., and Andreae, M. O.: Analysis of aircraft and satellite measurements from the Intercontinental Chemical Transport Experiment (INTEX-B) to quantify long-range transport of East Asian sulfur to Canada, Atmos. Chem. Phys., 8, 2999-3014, doi:10.5194/acp-8-2999-2008, 2008.

Wang, L. T., Hao, J. M., He, K. B., Wang, S. X., Li, J. H., Zhang, Q., Streets, D. G., Fu, J. S., Jang, C. J., Takekawa, H., and Chatani, S.: A modeling study of coarse particulate matter pollution in Beijing: Regional source contributions and control implications for the 2008 summer Olympics, J. Air Waste Manage., 58, 10571069, 2008.
Whelpdale, D. M., Dorling, S. R., Hicks, B. B., and Summers, P. W.: Atmospheric process, in: Global Acid Deposition Assessment, edited by: Whelpdale, D. M. and Kaiser, M. S., World Meteorological Organization Global Atmosphere Watch, Report Number 106, Geneva, 7-32, 1996.

Wild, M., Gilgen, H., Roesch, A., Ohmura, A., Long, C. N., Dutton, E. G., Forgan, B., Kallis, A., Russak, V., and Tsvetkov, A.: From dimming to brightening: Decadal changes in solar radiation at Earth's surface, Science, 308, 847-850, 2005.

Wild, M.: Global dimming and brightening: A review, J. Geophys. Res., 114, D00d16, doi:10.1029/2008jd011470, 2009.

Wild, M., Truessel, B., Ohmura, A., Long, C. N., Konig-Langlo, G., Dutton, E. G., and Tsvetkov, A.: Global dimming and brightening: An update beyond 2000, J. Geophys. Res., 114, D00d13, doi:10.1029/2008jd011382, 2009.

Witte, J. C., Schoeberl, M. R., Douglass, A. R., Gleason, J. F., Krotkov, N. A., Gille, J. C., Pickering, K. E., and Livesey, N.: Satellite observations of changes in air quality during the 2008 Beijing Olympics and Paralympics, Geophys. Res. Lett., 36, L17803, doi:10.1029/2009g1039236, 2009.

Xia, X., Li, Z., Wang, P., Chen, H., and Cribb, M.: Estimation of aerosol effects on surface irradiance based on measurements and radiative transfer model simulations in northern China, J. Geophys. Res., 112, D22s10, doi:10.1029/2006jd008337, 2007.

Xu, Y., Williams, R. H., and Socolow, R. H.: China's rapid deployment of $\mathrm{SO}_{2}$ scrubbers, Energ. Environ. Sci., 2, 459-465, 2009.

Yang, X.: Analysis and forecast of China's gasoline, kerosene and diesel oil market, Petroleum Petrochem. Today, 9, 13-18, 2001 (in Chinese).

Zhang, Q., Streets, D. G., He, K., Wang, Y., Richter, A., Burrows, J. P., Uno, I., Jang, C. J., Chen, D., Yao, Z., and Lei, Y.: $\mathrm{NO}_{\mathrm{X}}$ emission trends for China, 1995-2004: The view from the ground and the view from space, J. Geophys. Res., 112, D22306, doi:10.1029/2007jd008684, 2007a.

Zhang, Q., Streets, D. G., He, K. B., and Klimont, Z.: Major components of China's anthropogenic primary particulate emissions, Environ. Res. Lett., 2, 045027, doi:10.1088/17489326/2/4/045027, 2007b.

Zhang, Q., Streets, D. G., Carmichael, G. R., He, K. B., Huo, H., Kannari, A., Klimont, Z., Park, I. S., Reddy, S., Fu, J. S., Chen, D., Duan, L., Lei, Y., Wang, L. T., and Yao, Z. L.: Asian emissions in 2006 for the NASA INTEX-B mission, Atmos. Chem. Phys., 9, 5131-5153, doi:10.5194/acp-9-5131-2009, 2009a.

Zhang, Q., Streets, D. G., and He, K. B.: Satellite observations of recent power plant construction in Inner Mongolia, China, Geophys. Res. Lett., 36, L15809, doi:10.1029/2009gl038984, 2009b.

Zhao, Y., Wang, S. X., Duan, L., Lei, Y., Cao, P. F., and Hao, J. M.: Primary air pollutant emissions of coal-fired power plants in China: Current status and future prediction, Atmos. Environ., 42, 8442-8452, 2008.

Zhao, Y., Duan, L., Xing, J., Larssen, T., Nielsen, C. P., and Hao, J. M.: Soil acidification in China: Is controlling $\mathrm{SO}_{2}$ emissions enough?, Environ. Sci. Technol., 43, 8021-8026, 2009. 